\title{
AUTISTIMIKIRJON POIKIEN INTONAATION KÄYTTÖ KYSYMYS- JA KERRONTAVUOROISSA SPONTAANISSA VUOROVAIKUTUKSESSA
}

\author{
Mari Wiklund, Helsingin yliopisto, Kielten osasto
}

\author{
Kia Ihaksinen, Helsingin yliopisto, \\ Digitaalisten ihmistieteiden osasto
}

\author{
Martti Vainio, Helsingin yliopisto, \\ Digitaalisten ihmistieteiden osasto
}

Autismikirjon häiriö on aivojen neurobiologinen kehityshäiriö, jota luonnehtivat $\mathrm{mm}$. sosiaalisen vuorovaikutuksen ongelmat, aistiyliherkkyydet sekä rajoittuneet kiinnostuksen kohteet (APA, 2013). Autismikirjon henkilöillä puheen prosodiaan liittyy usein epätyypillisiä piirteitä. Tässä artikkelissa tarkastellaan autismikirjon poikien puheen lausumanloppuista nousevaa intonaatiota ja sen käyttöä kysymys- ja kerrontavuoroissa spontaanissa vuorovaikutuksessa. Aihe on tärkeä, koska vaikka autismikirjoon liittyviä prosodisia piirteitä onkin jo tutkittu melko paljon, spontaania puheaineistoa, joka mahdollistaisi autismikirjon henkilöiden intonaation käytön havainnoimisen, ei ole aiemmin juurikaan tutkittu.

Tutkimuksen aineistona käytetään autenttisia ryhmäkuntoutuskeskusteluja, joissa 11-13-vuotiaat autismikirjon pojat $(n=7)$ keskustelevat kuntouttajiensa kanssa. Tutkimuksessa käytetään fonetiikan ja keskustelunanalyysin menetelmiä.

Tutkimuksen tulokset viittaavat siihen, että autismikirjon pojat osaavat käyttää nousevaa loppuintonaatiota vuorovaikutuskeinona sekä tuottaa että tulkita oikein päättyvyyttä ilmaisevia prosodisia piirteitä spontaanissa vuorovaikutuksessa. He osaavat myös käyttää prosodisia piirteitä korostuskeinoina, kutsua intonaation loppunousun avulla reaktioita muilta osallistujilta sekä ilmaista vastaanottajan huomioonottamista. Autismikirjon pojat vaikuttaisivat siis pystyvän käyttämään hyväkseen intonaatiota vuorovaikutuksellisena resurssina, vaikka vastavuoroinen vuorovaikutus on yleisesti ottaen autismikirjon henkilöille vaikeaa (APA, 2013).

Avainsanat: autismi, autismikirjo, intonaatio, keskustelunanalyysi, prosodia, vuorovaikutus

Kirjoittajien yhteystiedot:

Mari Wiklund

mari.wiklund@helsinki.fi
Kia Ihaksinen

kia.ihaksinen@helsinki.fi
Martti Vainio

martti.vainio@helsinki.fi 


\section{JOHDANTO}

Tässä artikkelissa tarkastellaan esiteini-ikäisten autismikirjon poikien puheen lausumanloppuista nousevaa intonaatiota ja sen käyttöä kysymys- ja kerrontavuoroissa spontaaneissa ryhmäkuntoutuskeskusteluissa. Käytännössä tarkoitamme tässä yhteydessä 'intonaatiolla' sävelkulun eli perustaajuuden muutoksia. Tutkimus on kvalitatiivinen. Tutkimuksen päämääränä on havainnoida autismikirjon poikien lausumanloppuisen intonaation nousun käyttöä kysymys- ja kerrontavuoroissa suhteessa aiempaan tutkimuskirjallisuuteen. Pyrimme vastaamaan seuraaviin tutkimuskysymyksiin: 1) Esiintyykö autismikirjon poikien kysymys- ja/tai kerrontavuoroissa toistuvasti myös nousevaa intonaatiota? 2) Jos nousevaa intonaatiota esiintyy, vastaako sen käyttö aiemmassa tutkimuskirjallisuudessa esitettyä käyttöä suomen kielessä? 3) Käyttävätkö tutkittavat henkilöt muita prosodisia piirteitä vuorovaikutuksellisina resursseina?

Artikkelimme aihe on tärkeä, koska vaikka autismikirjoon liittyviä prosodisia piirteitä onkin jo tutkittu aiemmin melko paljon, spontaania puheaineistoa, joka mahdollistaisi autismikirjon henkilöiden intonaation käytön havainnoimisen, ei ole aiemmin juurikaan tutkittu. Lisäksi prosodian käyttöä ei toistaiseksi vielä oikeastaan opeteta autismikirjon lasten ryhmäkuntoutuksessa (Wiklund \& Stevanovic, 2018). Tästä syystä johtuen on tulevaisuutta ajatellen tärkeää saada tutkittua tietoa siitä, millaisia poikkeavuuksia autismikirjon poikien puheen intonaation käytössä mahdollisesti on.

Tutkimuksessa käytetään fonetiikan ja keskustelunanalyysin menetelmiä. Tutkimusidea ja kvantitatiiviset tulokset pohjautuvat Ihaksisen (2019) Helsingin yliopistossa tekemään fonetiikan alan pro gradu -tutkielmaan, jonka ohjaajina toimivat tämän artikkelin kaksi muuta kirjoittajaa. Kirjallisuuskatsaus, kvalitatiiviset analyysit sekä tulosten pohdinta on kirjoitettu uudestaan pro gradu -työn valmistumisen jälkeen.

Seuraavassa alaluvussa (1.1) tiivistämme autismikirjon henkilöiden prosodiaan liittyviä tutkimuksia. Sen jälkeen (1.2) käymme läpi kysymysten ja kerrontavuorojen intonaatiota sekä seuraavan puhujan valintaa yleisellä tasolla.

\subsection{Autismi ja prosodia}

Autismikirjon häiriö on aivojen neurobiologinen kehityshäiriö, jota luonnehtivat $\mathrm{mm}$. sosiaalisen vuorovaikutuksen ongelmat, aistiyliherkkyydet sekä rajoittuneet kiinnostuksen kohteet (APA, 2013). Tämä tutkimus kohdistuu autismikirjon poikien puheen prosodiaan. Fonetiikassa prosodisilla piirteillä tarkoitetaan yleensä painotukseen, kestoon, sävelkulkuun, kuuluvuuteen, puhenopeuteen ja puherytmiin liittyviä ilmiöitä, jotka koskevat vähintään tavun laajuisia yksiköitä puheessa (Crystal, 1969, 1980; Iivonen \& Aulanko, 2001)1. Tässä yhteydessä termi 'prosodia' käsitetään laajassa merkityksessä: myös tauot, tavujen venytykset sekä äänenkäytön paralingvistiset piirteet (hengitykset, nariseva ääni, nasaalinen ääni ja kuiskaukset) luetaan prosodian parametreiksi (Couper-Kuhlen, 2000). Autismikirjon henkilöillä puheen prosodiaan liittyy usein epätyypillisiä piirteitä. Puhe voi esimerkiksi olla melodisesti huomattavan tasaista, poikkeuksellisen nopeaa, nykivää ja/ tai voimakasta tai päinvastoin sellaista, jossa sävelkulun vaihtelut ovat huomattavan suuria, tai puhe on hyvin hiljaista. Autismikirjon henkilöiden puhetta voivat myös luonnehtia mm. epäjohdonmukainen taukorakenne, poikkeava painotus ja/tai nariseva tai nasaalinen ääni (Baltaxe \& Simmons, 1985, 1992; Fay \& Schuler, 1980; Ghaziuddin \& Gerstein, 1996; Lehtinen, 2010a; McPartland \& Klin,

\footnotetext{
Tässä tutkimuksessa prosodiaa käsitellään lausumatasolla. 'Lausuma' on siis laajin yksikkö, jota prosodia tässä tutkimuksessa koskee.
} 
2006; Ornitz \& Ritvo, 1976; Paul, 1987; Paul, Augustyn, Klin \& Volkmar, 2005a; Paul ym., 2005b; Provonost, Wakstein \& Wakstein, 1966; Rutter \& Lockyer, 1967; Shriberg ym., 2001; Tager-Flusberg, 1981; Tager-Flusberg, 2000; Thorson, Usher, Patel \& Tager-Flusberg, 2016; Wiklund \& Vainio, 2019).

Wiklundin ja Vainion (2019) suomea ja ranskaa koskevan tutkimuksen mukaan prosodiset ääripäät ylipäänsä ovat tavallisia autismikirjon henkilöiden puheessa. Kirjoittajien (2019) tulokset osoittavat myös, että esiteiniikäisten autismikirjon poikien puheessa esiintyy sekä poikkeavaa tasaisuutta että melodisesti poikkeavia, kielispesifejä kuvioita.

Autismikirjon henkilöiden puheen prosodiaa on aiemmin tutkittu ennen kaikkea englanninkielisissä aineistoissa. Thorson ja kollegat (2016) tutkivat niukasti puhuvien amerikanenglantia puhuvien autismikirjon lapsien ja nuorten spontaania puhetta. Heidän tuloksensa osoittavat, että keskimääräinen sävelkorkeus ja sävelkorkeuden vaihteluala muuttuivat suhteessa verbaaliseen kyvykkyyteen. Toisin sanottuna keskimääräinen sävelkorkeus ja sävelkorkeuden (perustaajuu$\operatorname{den}, f_{0}$ ) vaihteluala kummatkin laskivat samalla kuin tuotettujen leksikaalisten yksiköiden määrä nousi. Kun Thorson ja kollegat (2016) vertailivat omaa aineistoaan Diehlin, Watsonin, Bennetton, McDonoughin ja Gunlogsonin (2009) aiemmin julkaisemiin tuloksiin, kirjoittajat havaitsivat, että vähiten puhuvalla ryhmällä oli tyypillisesti suurin sävelkorkeuden vaihteluala.

Baltaxe (1984) vertaili 4-12-vuotiaiden autismikirjon lasten puhetta afaattisten lasten sekä verrokkiryhmän puheeseen. Tulokset osoittivat, että autismikirjon lasten ja verrokkiryhmän lasten perustaajuuden vaihteluala oli laajempi kuin afaattisten lasten. Fosnot'n ja Junin (1999) tutkimuksessa puolestaan autismikirjon lapsilla oli laajempi perustaa- juuden vaihteluala kuin verrokkiaineiston samanikäisillä lapsilla.

Peppén, McCannin, Gibbonin, O'Haren ja Rutherfordin (2007) mukaan autismikirjon lapset menestyvät tyypillisesti kehittyneitä lapsia sekä aikuisia verrokkeja heikommin reseptiivisissä ja ekspressiivisissä prosodiatehtävissä. Fine, Bartolucci, Ginsberg ja Szatmari (1991) ovat kuitenkin todenneet, että autismikirjon henkilöt osaavat käyttää viestinnän kannalta hyödyllisiä prosodisia kuvioita puheessaan. Oikeanlaisten painotusten tuottaminen voi kuitenkin olla heille vaikeaa (Paul ym., 2005a, 2005b). Shriberg ja kollegat (2001) ovat havainneet, että autismikirjon henkilöillä on huomattavia vaikeuksia prosodian pragmaattisessa ja affektiivisessa käytössä. Sen sijaan heillä ei ole ongelmia prosodian kieliopillisten tehtävien hallinnassa (Shribergym., 2001).Sama tutkimus osoittaa, että autismikirjon henkilöiden puheessa on enemmän epäsujuvuutta kuin neurotyypillisten henkilöiden puheessa ${ }^{2}$.

Olivati, Assumpção ja Nunes Misquiatti $(2017)^{3}$ analysoivat autismikirjon opiskelijoiden puhekatkelmia ja vertailivat niitä verrokkiryhmän puheeseen. He löysivät merkittäviä eroja äänialassa, puheen maksimi-intensiteetissä, puheen minimi-intensiteetissä, painollisen tavun kestossa ja melodiassa, painollista tavua edeltävän tavun kestossa ja melodiassa sekä ilmaisujen kestossa.

Poikkeavat prosodiset piirteet eivät kuitenkaan koske jokaista autismikirjon henkilöä (Paul ym., 2005b; Simmons \& Baltaxe, 1975). Mutta silloin, kun poikkeavia piirteitä esiintyy, niistä voi olla merkittävää haittaa yksilön sosiaalisen hyväksynnän kannalta (Paul

2 Enemmän epäsujuvuudesta suomenkielisten autismikirjon henkilöiden puheessa, ks. esim. Wiklund \& Laakso (2019).

3 Olivati ja kollegat (2017) tutkivat brasilianportugalinkielistä aineistoa. Muuten kirjallisuuskatsauksessa viitatut autismikirjon henkilöiden puheen prosodiaan liittyvät tutkimukset ovat kohdistuneet englanninkieliseen aineistoon, mikäli kieltä ei ole erikseen mainittu. 
ym., 2005a, s. 205). Poikkeavat prosodiset piirteet saattavat nimittäin luoda välittömän vaikutelman "kummallisuudesta" (Van Bourgondien \& Woods, 1992), ja ne vaikuttavat autismikirjon henkilöiden sosiaalisen ja kommunikatiivisen kyvykkyyden tasoarviointiin (Paul ym., 2005b).

Havaintojemme mukaan autismikirjon poikien puheen prosodiset piirteet ovat harvoin ymmärrysongelmien ensisijainen aiheuttaja (Lehtinen, 2012; Wiklund, 2016; Wiklund \& Stevanovic, 2018; Wiklund \& Vainio, 2019), mutta on huomionarvoista, että ymmärrysongelmiin johtaviin "ongelmapuheenvuoroihin" useimmiten liittyy tiettyjä epätyypillisiä prosodisia piirteitä kuten narisevaa ääntä, hiljaista ääntä tai suuria sävelkorkeuden vaihteluita (Wiklund, 2016). Mainitut tutkimukset pohjautuvat samaan aineistoon kuin tämä artikkeli.

\subsection{Kysymysten ja kerrontavuorojen intonaatiosta sekä seuraavan pubujan valinnasta}

Iivosen (1998, s. 317) mukaan suomessa laskeva intonaatiokontuuri koskee yleisesti ottaen sekä kysymyksiä että toteamuksia. Kysymyksissä ja toteamuksissa on Iivosen tutkimuksen (2009, s. 73) mukaan sama sävelkorkeuden lopputaso: se on kummassakin matala. Soinnittomuus ja nariseva ääni ovat suomessa tavallisia lausuman lopussa (Iivonen 2006, 2009). Kysymysten alkusävelkorkeus on korkea, kun taas toteamuksissa se on selvästi matalampi. Toteamusten sävelala on kapea, kun taas kysymyksissä se on hyvin laaja (Iivonen, 2009, s. 73). Toteamusten sävelkulun kokonaismuoto on laskeva. Kysymyksissä sävelkulku nousee viimeiseen sanaan asti ja sitten laskee. Toteamusten painotus on kauttaaltaan heikkoa. Kysymyksissä puolestaan viimeinen sana on voimakkaasti painotettu (Iivonen, 2009, s. 73).
Toisin kuin monissa muissa kielissä, suomessa lausumanloppuinen intonaation nousu ei ole kieliopillistunut kysymyksen merkiksi (Hirvonen, 1970; Iivonen, 1978, 1998; Kallioinen, 1968; Routarinne, 2003, s. 179-183). Nousevaa intonaatiota on perinteisesti pidetty ongelmallisena suomen intonaatiota koskevissa tutkimuksissa. Vakiintuneen käsityksen mukaan intonaation loppunousut ovat harvinaisia, eikä niitä esiinny systemaattisesti (Iivonen, 1998, 2001). Kuitenkin lausumat voivat suomessa päättyä myös intonaation nousuun (Iivonen, 1978), ja spontaanin puheen intonaatiokontuurit ovat yleisesti ottaen vaihtelevia (Iivonen, Nevalainen, Aulanko \& Kaskinen, 1987). Ogden ja Routarinne (2005, s. 160) huomauttavat myös, että valtaosa suomen intonaatiota koskevista tutkimuksista on kohdistunut monologiseen tai luettuun puheeseen, ja että lausumanloppuiset intonaation nousut ovat itse asiassa tavallisia spontaanissa puheessa.

Iivonen (1998, s. 326) ja Anttila (2008) ovat todenneet, että suomessa sävelkulun loppunousuja esiintyy erityisesti liitekysymyksissä ja elliptisissä kysymyksissä. Anttilan (2009) spontaaniin puheaineistoon perustuvan tutkimuksen tuoma uusi tulos kysymyksiin liittyen on se, että erityyppisissä kysymyksissä esiintyy itse asiassa toistuvasti nousevaa sävelkulkua. Kirjoittaja mainitsee tämän voivan johtua esimerkiksi interferenssistä vieraista kielistä, kuten englannista (Anttila, 2009, s. 176). Kyse voi olla myös "uudesta tavasta" vedota kuulijaan (Anttila, 2009, s. 176) tai ilmaista kohteliaisuutta (Anttila, 2008, s. 90).

Iivonen toteaa (1978), että lausumanloppuiset intonaation nousut ilmaisevat usein jatkuvuutta suomessa. Routarinteen (2003) nuorten tyttöjen puhetta koskevat tulokset ovat samansuuntaisia. Routarinteen (2003, s. 170) mukaan lausumanloppuiset intonaation nousut esiintyvät tyypillisesti kerrontasekvensseissä ja ilmaisevat, että kertoja aikoo 
vielä jatkaa puhumista (ks. myös Lehtinen, 2010b). Ilmiö luo odotuksia kerrontalinjan jatkumisesta, ja se esiintyy usein lausumissa, jotka ohjaavat vastaanottajan huomiota kohti tarinan jatkumista. Lausumanloppuinen intonaation nousu on myös vuorovaikutuksellinen resurssi, joka kutsuu puhekumppanin reaktiota (Routarinne, 2003, s. 170) ja osoittaa täten, että puhuja ottaa vastaanottajan huomioon (s. 183). Ogden ja Routarinne (2005, s. 173) ovatkin osoittaneet, että lausumanloppuiset intonaation nousut johtavat usein puhekumppanin tuottamaan minimipalautteeseen, jonka avulla puhekumppani voi merkitä itsensä sanotun vastaanottajaksi.

Routarinteen (2003, s. 169) tulokset osoittavat, että valtaosa (74\%) loppunousulla merkityistä lausumista on toteavia lausumia tai niiden osia. Loppunousuiset lausumat kuvaavat yleensä asiaintilaa, jonka oletetaan olevan puhekumppanien yhteistä tietoa. Lausumanloppuiset intonaation nousut esiintyvät tavallisesti kertomuksen orientoivissa osissa, joissa puhuja kuvailee varsinaisten tapahtumien olosuhteita (Routarinne, 2003, s. 183-188). Loppunousu ilmaisee, mihin taustainformaatio tulisi suhteuttaa (Routarinne, 2003, s. 187). Toisin sanottuna loppunousu projisoi kerrontalinjan jatkumista sekä huippukohtaa tai muuta jatkoa, jonka ymmärtämisen kannalta loppunousun avulla merkityn lausuman sisältämä informaatio on erityisen tärkeää.

Monen henkilön kesken käydyssä keskustelussa seuraavan puhujan valinta voidaan tehdä esimerkiksi puhuttelemalla jotakin osallistujaa nimellä tai suuntaamalla katse johonkin osallistujaan (Ruusuvuori, 2016, s. 55). On myös todettu, että puheen vuorottelussa vuoron vaihtumista ilmaistaan monin eri tavoin kuten leksikaalisin, kieliopillisin ja prosodisin keinoin (Couper-Kuhlen, 2004, s. 371-372). Pelkkä katseen käyttö tutkimassamme aineistossa olisi sikäli ongelmallista, että usein autismikirjon henkilöt välttelevät katsekontaktia eivätkä täten välttämättä huomaisi heihin kohdistuvaa katsetta (Wiklund, 2012).

\section{AINEISTO JA METODIT}

\subsection{Aineisto}

Tutkimuksen aineistona käytetään autenttisia ryhmäkuntoutuskeskusteluja, joissa 11-13-vuotiaat autismikirjon pojat keskustelevat kuntouttajiensa kanssa. Ryhmiä on kaksi, ryhmä A ja ryhmä B. Ryhmä A:n istunto on äänitetty marraskuussa 2009 ja ryhmä B:n istunto helmikuussa 2010. Ryhmät ovat keskenään rinnakkaisia, ja niiden kokoonpanot ovat määräytyneet sattumanvaraisesti. Tämän artikkelin ensimmäinen kirjoittaja oli paikalla aineistonkeruutilanteissa peililasin takana siten, että osallistujat eivät nähneet häntä. Hän ei siis vaikuttanut istuntojen kulkuun. Osallistujilta kerättiin vanhempien sekä tutkittavien henkilöiden omalla informoidulla suostumuksella seuraavat tiedot: nimi, syntymäaika, äidinkieli, diagnoosit, kotiosoite ja sähköpostiosoite. Tutkimuksella on sairaanhoitopiirin naisten, lasten ja psykiatrian eettisen toimikunnan puoltava lausunto sekä tutkimuslupa, jota on jatkettu kerran.

Istunnot alkoivat kuulumisten vaihdolla. Tämän jälkeen ryhmät keskustelivat kuvakorttien avulla koulukiusaamisesta. Ryhmässä A oli paikalla kolme poikaa ja kaksi kuntouttajaa. Ryhmässä B puolestaan oli paikalla neljä poikaa ja kaksi kuntouttajaa. Täten tutkittujen henkilöiden yhteismäärä on seitsemän ( $\mathrm{n}$ $=7$ ). Toinen kuntouttajista oli mies ja toinen nainen. Miespuolinen kuntouttaja oli sama kummassakin istunnossa, naispuolinen kuntouttaja ei. Kaikkien poikien ainoa äidinkieli on suomi. Viidellä seitsemästä pojasta oli Aspergerin oireyhtymä -diagnoosi nauhoitushetkellä. Kummassakin ryhmässä on myös mukana yksi poika, jolla ei ollut mitään autismikirjon diagnoosia nauhoitushetkellä. Kuntouttajien mukaan heillä kuitenkin oli 
samanlaisia autismikirjolle tyypillisiä piirteitä kuin muillakin osallistujilla, ja he olivat mukana kuntoutusryhmissä nimenomaan näiden piirteiden takia. Pojat asuvat kaikki pääkaupunkiseudulla - osa Helsingissä, osa pääkaupunkiseudun muissa kaupungeissa. Heidän syntymäpaikoistaan meillä ei ole tietoa eikä siitä, kuinka pitkään kukin on asunut pääkaupunkiseudulla. Kaikki puhuvat kuitenkin mielestämme tyypillistä Helsingin suomea.

Aspergerin oireyhtymä oli aiemmin oma spesifi diagnoosinsa (APA, 2000), mutta nykyään se sisältyy laajempaan autismikirjon diagnostiseen kategoriaan laajasti käytössä olevassa DSM-5-luokituksessa (APA, 2013). Asperger-diagnoosi on poistumassa myös WHO:n ICD-11-luokituksesta, jonka on määrä tulla voimaan vuonna 2022. Jatkossa tullaan siis puhumaan vain autismikirjon häiriöstä. Täten viittaamme artikkelissamme tutkittaviin henkilöihin puhumalla vain 'autismikirjon pojista', tms., emmekä juurikaan viittaa heidän Asperger-diagnoosiinsa. Emme edellä mainitusta syystä johtuen myöskään luokittele kirjallisuuskatsauksessa mainittuja tutkimuksia sen mukaan, mitkä niistä käsittelevät spesifisti Aspergerin oireyhtymää ja mitkä autismikirjoa yleisesti.

Kumpikin istunto on äänitetty Helsingissä. ${ }^{4}$ Tutkitun aineiston yhteiskesto on kaksi tuntia (yksi tunti per ryhmä). Aineisto on kuvattu kahdella videokameralla ja äänitetty kunkin pojan korvan taakse kiinnitetyn sankamikrofonin avulla. Sankamikrofonin ansiosta etäisyys puhujan suun ja mikrofonipinnan välillä pysyi samana koko nauhoituksen ajan ja puhujien liikkumisesta ja äänitysitilasta johtuvat vaihtelut jäivät minimaalisiksi. Nauhoituksen toteuttivat audiovisuaalisen viestinnän ammattilaiset.

\footnotetext{
4 Tarkempaa paikkaa emme mainitse tutkimuseettisis-
} tä syistä johtuen.
Aineisto on kokonaisuudessaan annotoitu Praat-puheanalyysiohjelman (Boersma \& Weenink, 2019) avulla. Lisäksi aineisto on litteroitu keskustelunanalyysin konventioita käyttäen (Seppänen, 1997). Lista käytetyistä litterointimerkeistä löytyy artikkelin lopusta.

\subsection{Menetelmät}

Tutkimuksessa käytetään siis fonetiikan ja keskustelunanalyysin (KA) menetelmiä. KA:ssa tutkitaan nauhoitettua, luonnollisesti esiintyvää vuorovaikutusta. Päämääränä on selvittää, kuinka vuorovaikutuksen osallistujat ymmärtävät toisiaan ja reagoivat toistensa puheenvuoroihin luoden vuorovaikutukseen erilaisia toimintasekvenssejä (Hutchby \& Wooffitt, 2008, s. 12). Suhteessa kokeelliseen tutkimukseen epätyypillisten ja epäsymmetristen vuorovaikutustilanteiden - kuten aineistomme kuntoutus-keskustelujen - tutkiminen KA:n menetelmin tarjoaa mahdollisuuden havainnoida osallistujien välistä yhteistyötä sekä osallistujien vuorovaikutuksellisia taitoja. Täten KA:n menetelmien käyttö voi johtaa osallistujien mahdollisten vuorovaikutusongelmien aiheuttajien ja seurausten löytämiseen ja täten ongelmien parempaan ymmärtämiseen (Damico \& Nelson, 2005; Wiklund \& Laakso, 2019). KA:n menetelmien yhdistäminen fonetiikan menetelmiin puolestaan mahdollistaa tutkittavien yksiköiden - meidän tutkimuksemme tapauksessa kysymys- ja kerrontavuorojen - tarkan prosodisen analysoimisen. ${ }^{5}$ Kuten jo yllä on mainittu, nousevaa intonaatiota on aiemmin tutkittu suomenkielisessä aineistossa KA:n menetelmin nuorten tyttöjen puheessa (Ogden \& Routarinne, 2005; Routarinne, 2003). Koska meidän aineistomme tutkittavat henkilöt ovat kaikki poikia, tutkimuksemme tuo uutta kiinnostavaa tietoa nousevan intonaa-

\footnotetext{
5 KA:n ja fonetiikan yhdistämisestä prosodian analy-
} soimiseksi ks. esim. Stevanovic (2016). 
tion käytöstä suomen kielessä yleensä. Toisin sanottuna tutkimuksemme antaa viitteitä siitä, koskevatko aiempien tutkimusten nuorten tyttöjen puhetta koskevat havainnot myös nuorten poikien puhetta, vai onko nousevan intonaation käyttö erilaista tytöillä ja pojilla.

Aineisto on ensin käyty läpi siten, että siitä laskettiin kunkin pojan puheenvuorojen yhteislukumäärä sekä se, kuinka monessa puheenvuorossa esiintyi lausumanloppuista nousevaa intonaatiota. Laskutoimitusten jälkeen puheenvuorot analysoitiin esiintymiskonteksteissaan KA:n menetelmiä käyttäen. Pyrimme mm. selvittämään, miksi kussakin kohdassa esiintyi nousevaa intonaatiota. Intonaation lisäksi otimme analyyseissämme huomioon myös vuoron muita prosodisia piirteitä, kuten äänenlaadun. Tämän jälkeen laskimme vielä erikseen kuinka monessa kohdassa nousevaa intonaatiota käytettiin kysymyksessä ja kuinka monessa ei, jolloin saimme kuvan siitä, käytetäänkö nousevaa intonaatiota myös muunlaisissa vuoroissa kuin kysymyksissä.

'Kysymys' on tutkimuksessamme lausuma, joka kuuluu vastaanottajan episteemiselle kentälle ja joka muodostaa ensimmäisen osan vierusparista, johon kuuluu kysymys ja vastaus (Huhtamäki, 2015, s. 18-22). 'Lausumalla' tarkoitamme puheen toiminnallista ja prosodista jaksoa, jolla on tietty tehtävä ja joka edustaa jotakin puhetoimintoa. Puheenvuoro sisältää vähintään yhden lausuman. Kieliopillisesti lausuma voi olla yksi sana, lauseke, lause, jne. (ISK, 2004, \$ 1003). 'Kerrontavuoro'termiä käytämme tässä tutkimuksessa erittäin laajassa merkityksessä viittaamaan kaikkiin muihin kuin kysymysvuoroihin.

Foneettisissa analyyseissä otettiin huomioon perustaajuuskäyrän muutokset sekä perustaajuuden keskiarvo, minimiarvo ja maksimiarvo tutkittavien puheenvuorojen tuottamisen aikana. Foneettiset analyysit tehtiin Praat-puheanalyysiohjelman (Boers- ma \& Weenink, 2019) avulla. Käytämme tässä artikkelissa yleisesti termiä 'intonaatio' viittaamaan sävelkulun (perustaajuus, $f_{0}$ ) muutoksiin. Perustaajuuskäyrät on tarkistettu ja korjattu manuaalisesti spektrogrammin avulla. Esimerkiksi narisevan tai muuten eimodaalisen äänenlaadun aiheuttamat virheet perustaajuuskäyrissä on korjattu tai selitetty tekstissä. Asteikkona käytetään puolisävelasteikkoa, joka vastaa hertsiasteikkoa paremmin kuulohavaintoa ja mahdollistaa puhujien välisen vertailun. 'Nousevana intonaationa' käsiteltiin tässä tutkimuksessa kaikkia lausuman lopussa esiintyviä kuulonvaraisesti nousevia intonaatioita. Tarkkaa raja-arvoa ei siis ollut, vaan riitti, että kuulonvarainen vaikutelma lausuman lopussa oli selkeästi havaittava loppunousu.

\section{ANALYYSI: AUTISMIKIRJON POIKIEN KYSYMYS- JA KERRONTAVUOROJEN INTONAATIO}

\subsection{Lausumanloppuista intonaation nousua sisältävien pubeenvuorojen määrät}

Taulukko 1 havainnollistaa lausumanloppuista intonaation nousua sisältävien puheenvuorojen määrää autismikirjon poikien puheessa tutkimassamme aineistossa. Taulukosta voidaan todeta, että määrissä on suurta yksilöllistä vaihtelua: yhdellä pojista ('Hannulla'`) intonaation nousua sisältävien puheenvuorojen osuus kaikista vuoroista on peräti $34 \%$, kun taas toisella pojalla ('Ristolla') vastaava osuus on vain $2 \%$. Keskimäärin poikien puheessa esiintyvistä vuoroista $20 \%$ päättyy nousevaan intonaatioon. Valtaosa tutkitussa aineistossa esiintyvistä autismikirjon poikien tuottamista puheenvuoroista päättyy siis joko laskevaan

\footnotetext{
6 Osallistujien nimet on muutettu tutkimuseettisistä syistä johtuen.
} 
tai tasaiseen intonaatioon. Kuitenkin voidaan todeta, että nousevan loppuintonaation esiintyminen on aineistossa toistuvaa, mikä on jossain määrin linjassa aiempien suomen intonaatiota koskevien tutkimusten kanssa: Ogdenin ja Routarinteen (2005, s. 160) mukaan lausumanloppuiset intonaation nousut ovat tavallisia spontaanissa puheessa.

Taulukko 2 havainnollistaa lausumanloppuiseen intonaation nousuun päättyvien kysymyspuheenvuorojen osuutta kaikista kysymyspuheenvuoroista tutkitussa aineistossa: eniten nousevaan intonaatioon päättyviä kysymysvuoroja on 'Tonilla' (75
\%) ja 'Heikillä' (75 \%) ja vähiten 'Tommilla' (17\%). Keskimäärin $46 \%$ poikien puheessa esiintyvistä kysymyspuheenvuoroista päättyy nousevaan intonaatioon. Tämä tulos on linjassa Anttilan (2009) suomenkieliseen spontaaniin puheaineistoon perustuvan tutkimuksen kanssa, sillä kirjoittajan mukaan erityyppisissä kysymyksissä esiintyy toistuvasti nousevaa sävelkulkua. On kuitenkin huomattava, että kysymyspuheenvuorojen kokonaismäärä aineistossamme on suhteellisen pieni ( $48 \mathrm{kpl})$, joten tulosten yleistäminen ei ole mahdollista.

TAULUKKO 1: Vuorojen kokonaislukumäärä sekä lausumanloppuiseen intonaation nousuun päättyvät vuorot autismikirjon poikien puheessa.

\begin{tabular}{|l|l|l|l|}
\hline & $\begin{array}{l}\text { Nouseva intonaatio } \\
(\mathbf{k p l})\end{array}$ & $\begin{array}{l}\text { Kaikki puheenvuorot } \\
(\mathbf{k p l})\end{array}$ & $\begin{array}{l}\text { Nouseva intonaatio } \\
(\mathbf{\%})\end{array}$ \\
\hline Hannu & 73 & 215 & 34,0 \\
\hline Tommi & 30 & 157 & 19,1 \\
\hline Risto & 4 & 167 & 2,4 \\
\hline Toni & 23 & 105 & 21,9 \\
\hline Väinö & 21 & 122 & 17,2 \\
\hline Mikko & 41 & 216 & 19,0 \\
\hline Heikki & 25 & 98 & 25,5 \\
\hline Yhteensä & $\mathbf{2 1 7}$ & $\mathbf{1 0 8 0}$ & $\mathbf{2 0 , 1}$ \\
\hline
\end{tabular}

TAULUKKO 2: Kysymyspuheenvuorojen kokonaislukumäärä sekä lausumanloppuiseen intonaation nousuun päättyvät kysymyspuheenvuorot autismikirjon poikien puheessa.

\begin{tabular}{|l|l|l|l|}
\hline & $\begin{array}{l}\text { Nouseva intonaatio } \\
(\mathbf{k p l})\end{array}$ & $\begin{array}{l}\text { Kysymyspuheenvuorot } \\
(\mathbf{k p l})\end{array}$ & $\begin{array}{l}\text { Nouseva intonaatio } \\
(\mathbf{\%})\end{array}$ \\
\hline Hannu & 10 & 22 & 45,5 \\
\hline Tommi & 1 & 6 & 16,7 \\
\hline Risto & 1 & 3 & 33,3 \\
\hline Toni & 3 & 4 & 75,0 \\
\hline Väinö & 3 & 5 & 60,0 \\
\hline Mikko & 1 & 4 & 25,0 \\
\hline Heikki & 3 & 4 & 75,0 \\
\hline Yhteensä & $\mathbf{2 2}$ & $\mathbf{4 8}$ & $\mathbf{4 5 , 8}$ \\
\hline
\end{tabular}




\subsection{Kerrontavuoro ilman nousevaa intonaatiota}

Ensimmäinen esimerkki havainnollistaa tilannetta, jossa kerrontavuoroon ei sisälly nousevaa intonaatiota (rivi 09). 'Kerrontavuoro' on tässä tapauksessa käytännössä vastausvuoro. Katkelmassa ryhmä B keskustelee siitä, pitääkö kukaan koulusta. Väinö (rivi 04), Toni (rivit 05-06) ja Mikko (rivit 07-08) ovat sanoneet, että eivät tunne ketään, joka pitäisi koulusta. Tämän jälkeen naispuolinen kuntouttaja (NK) kysyy Tonilta (rivi 09), tunteeko tämä ketään, joka pitäisi koulusta. Ilmeisesti NK ei ollut kuullut Tonin aiempaa vastausta (rivit 05-06) päällekkäispuhunnan takia.

\section{Esimerkki 1. (autismi.suomi.2010)}

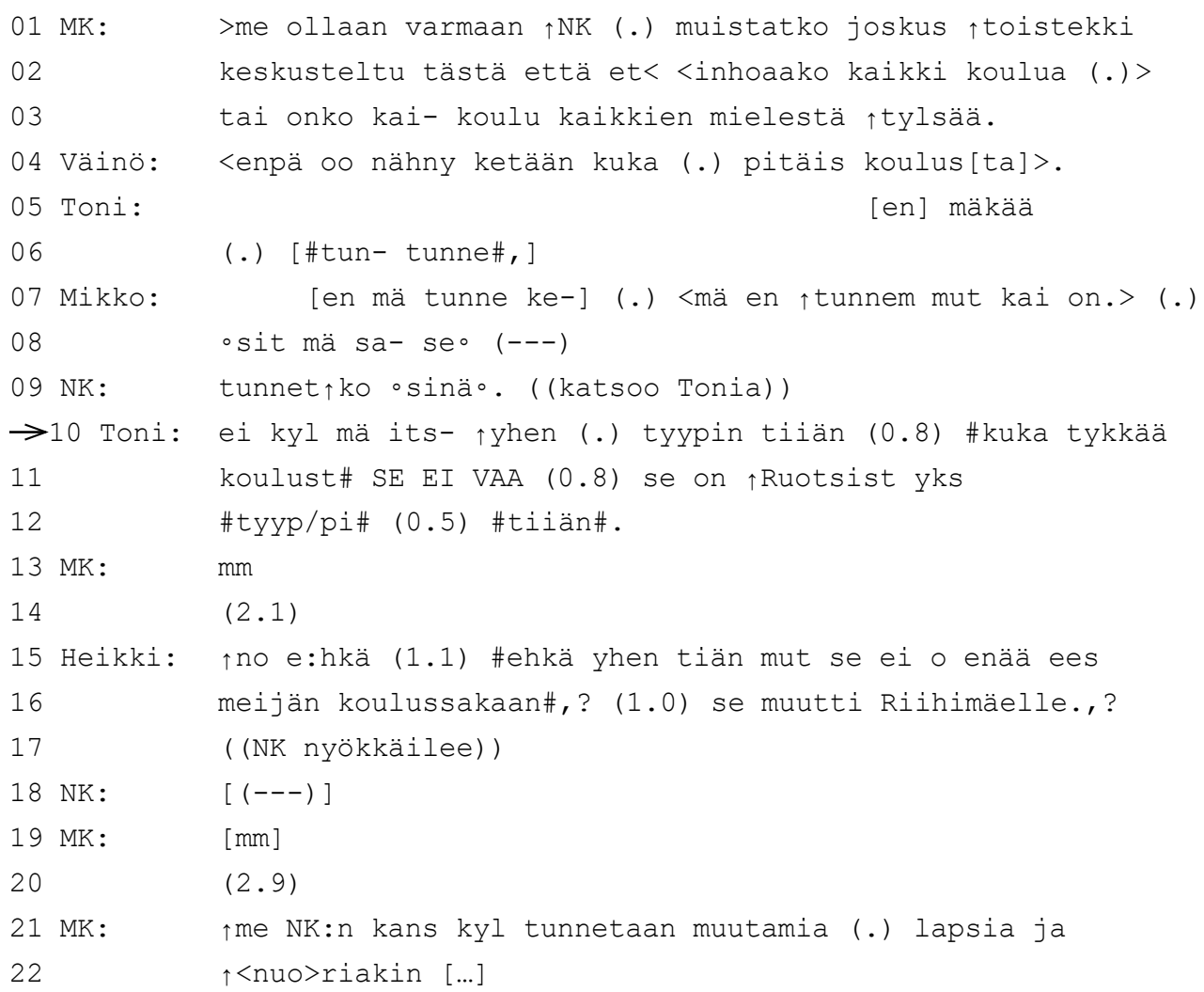

Toni vastaa kuntouttajan kysymykseen toteavalla vuorolla, jossa sanoo tuntevansa yhden koulusta pitävän henkilön (rivit 10-12). Tonin vastaus on mielenkiintoinen, koska se alkaa 'ei'-sanalla mutta antaa kuitenkin myöntävän vastauksen: 'ei kyl mä its- yhen tyypin tiiän' (rivi 10).'Ei'-sanan esiintyminen johtuu tässä siitä, että Toni on juuri sanonut, että ei tunne ketään, joka pitäisi koulusta (rivit 0506). Toisessa vastauksessaan (rivit 10-12) hän siis ensin kumoaa aiemman vastauksensa 'ei'sanalla ja antaa sitten myöntävän vastauksen. Sana 'yhen' on lausuttu ympäröivää puhetta korkeammalta sävelkorkeudelta. Tämä prosodinen muutos korostaa sitä, että Toni sittenkin tietää jonkun, joka pitää koulusta, ja 
toimii siis tavallaan yhteistyössä vuoron alun 'ei'-sanan kanssa. 'Tiïän'-sanaa seuraa pitkähkö tauko (0,8 sek) (rivi 10), joka luo kyseiseen kohtaan siirtymän mahdollistavan kohdan (SMK). Kyseisessä kohdassa vuoro voisi siis luontevasti siirtyä toiselle puhujalle (esim. Hakulinen, 1997).

Kukaan ei kuitenkaan ota puheenvuoroa itselleen, ja Toni jatkaa vielä vuoroaan sanoen narisevalla äänellä 'kuka tykkää koulust' (rivit 10-11). Nariseva ääni viitannee tässä siihen, että Toni on lopettelemassa vuoroaan (Ogden, 2004). Hän kuitenkin "muuttaa suuntaa", ts. "kumoaa" päättyvyyden implikoimisen tuottamalla heti narisevan jakson perään voimakkaalla äänellä sanat'se ei vaa' (rivi 11). Tämän jälkeen Tonin puheessa esiintyy jälleen pitkähkö tauko ( 0,8 sek). Vuoro vaikuttaa kuitenkin keskeneräiseltä, ja Toni jatkaakin tauon jälkeen vielä vuoroaan sanomalla'se on Ruotsist yks tyyppi' (rivit 11-12). Sanan 'Ruotsist' ensimmäinen tavu on lausuttu ympäristöä korkeammalta ja voimakkaasti painottaen. Täten Toni korostaa sitä asiantilaa, että kyseinen henkilö ei ole Suomesta vaan Ruotsista. Tauon jälkeen $(0,5$ sek) Toni tuottaa vielä sanan 'tiän' narisevalla äänellä, koska kukaan muu ei ole ottanut puheenvuoroa itselleen 'tiiän'-sanaa edeltävän SMK:n aikana. Nariseva ääni implikoi tässäkin päättyvyyttä (Ogden, 2004). Vuoro päättyy laskevaan intonaatioon. Miespuolinen kuntouttaja (MK) tarttuu syntyvään SMK:hon ja reagoi sanottuun kuulolla oloa ilmaisevalla dialogipartikkelilla 'mm' (rivi 13) (ISK, 2004, §798).
MK:n partikkelivuoron jälkeen kukaan ei heti reagoi mitenkään. Syntyy 2,1 sekuntia pitkä tauko (rivi 14). Tämän jälkeen Heikkikin rohkaistuu sanomaan, että itse asiassa hänkin ehkä tuntee yhden henkilön, joka pitää koulusta (rivit 15-16). NK reagoi hiljaiselta pojalta vaikuttavan Heikin spontaaniin puheenvuoroon nyökyttelemällä selväeleisesti (rivi 17). Hänen suullinen reaktionsa jää päällekkäispuhunnan takia epäselväksi (rivi 18). MK reagoi Heikin vuoroon kuulolla oloa ilmaisevalla dialogipartikkelilla 'mm' (rivi 19) (ISK, 2004, \$798). Tämän jälkeen syntyy 2,9 sekuntia pitkä tauko (rivi 20), jonka jälkeen MK ryhtyy kertomaan, kuinka hän ja NK tuntevat useita koulusta pitäviä lapsia ja nuoria (rivit 21-22). Tonin vuoro (rivit 10-12) aiheuttaa siis tietynlaisen käänteen keskustelussa, koska ennen sitä kukaan ei pitänyt koulusta.

On huomionarvoista, että esimerkkikatkelmassa Toni osaa käyttää prosodiaa korostamisen (sävelkulun nousu sanan alussa; painotus) sekä vuoron säilyttämisen (äänen voimakkuuden nostaminen) keinona. Hän myös jatkaa vuoroaan vielä SMK:n syntymisen jälkeen, koska kukaan muu ei ota puheenvuoroa itselleen sen aikana. Lisäksi Toni käyttää narisevaa ääntä ja laskevaa loppuintonaatiota implikoimaan vuoron päättymistä. Heikki puolestaan ottaa spontaanisti puheenvuoron 2,1 sekuntia pitkän hiljaisuuden jälkeen relevantilla aiheeseen liittyvällä edellisen puhujan kanssa samanmielisellä vuorolla. 


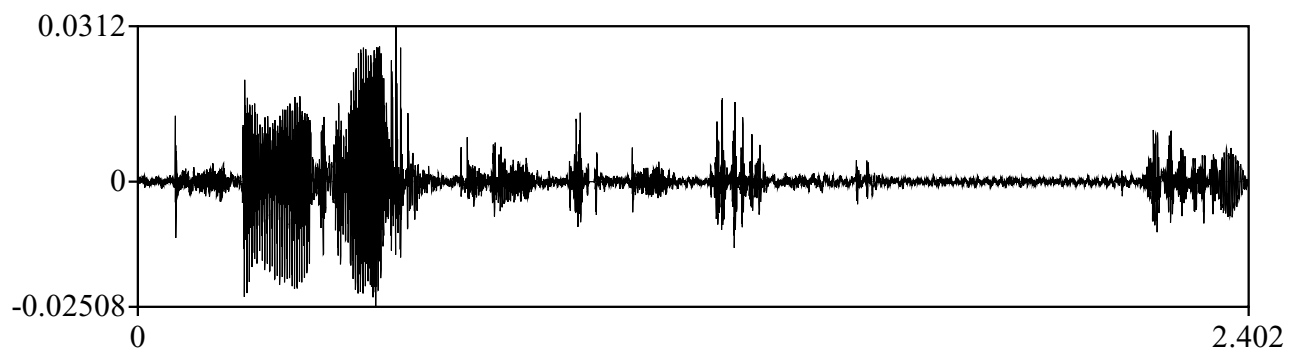

Time (s)

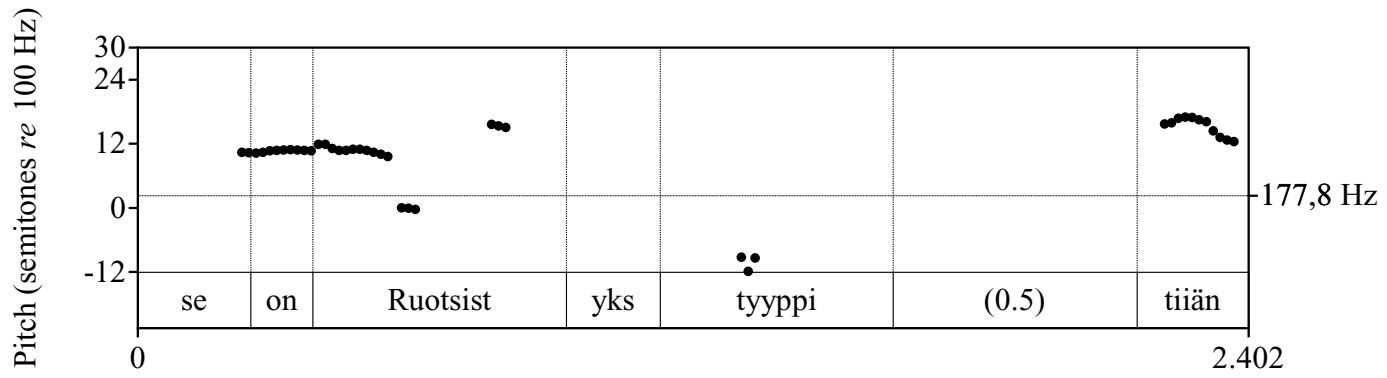

Time (s)

KUVIO 1: Perustaajuus- eli fo-käyrä Tonin kerrontavuoron viimeisen lausuman aikana (esimerkki 1).

Kuvio 1 havainnollistaa sävelkulun eli perustaajuuden muutoksia Tonin vuoron viimeisen lausuman ('se on Ruotsist yks tyyppi tiiän') aikana ${ }^{7}$. Perustaajuuden keskiarvo lausuman tuottamisen aikana on $215 \mathrm{~Hz}$. Maksimisävelkorkeus on $373 \mathrm{~Hz}$ ja minimisävelkorkeus $97 \mathrm{~Hz}$. Kuten kuviossa 1 näkyvä käyrä osoittaa, intonaatio on vuoron lopussa laskeva. Sen sijaan intonaatio nousee hiukan toiseksi viimeisen sanan, 'tyyppi', loppua koh-

\footnotetext{
Kuviossa näkyvä käyrä vastaa kuulohavaintoa intonaation kulusta tuotetun lausuman aikana lukuun ottamatta sitä, että sanan 'tyyppi' lopussa sävelkulu nousee hiukan kuulonvaraisesti tulkittuna, mutta narinan takia Praat ei tunnista nousua. Ääni narisee myös sanan 'tiïn' aikana, mikä aiheuttaa sen, että Praat ei pysty tunnistamaan puheen perustaajuutta. Sen sijaan Praat on löytänyt muuta jaksollisuutta puheesta, todennäköisesti vokaalin [i] ensimmäisen formantin. Kuten sanottu, käyrä vastaa kuitenkin auditorista vaikutelmaa lausumasta. Todennäköisesti vaikutelma tulee soinnittomassa puheessa toisen formantin kautta (Thomas, 1969). Sanan 'Ruotsist' aikana esiintyvät kaksi lyhyttä osaa ovat Praatin väärin estimoimia arvoja narinan aikana.
}

ti. Sana on tuotettu narisevalla äänellä, mistä syystä johtuen nousu ei näy käyrässä. Nousu sanan lopussa saattaa viestiä siitä, että puhuja kutsuu tässä kohdassa vastaanottajilta reaktiota (Routarinne, 2003, s. 170). Reaktiota ei kuitenkaan tule, vaikka sanaa seuraa 0,5 sekuntia pitkä tauko, jonka aikana muiden reagointi olisi ollut mahdollista. Täten puhuja jatkaa vielä vuoroaan tuottamalla sanan 'tiiän', joka on tuotettu narisevalla äänenlaadulla ja aiempaa puhetta hiljaisemmalla äänellä. Nämä piirteet viittaavat siihen, että vuoro on päättymässä (Ogden, 2004).

\subsection{Kerrontavuoro, joka päättyy nousevaan intonaatioon}

Toinen esimerkki havainnollistaa tilannetta, jossa autistisen pojan kerrontavuoro päättyy nousevaan intonaatioon (rivi 14). Esimerkki on otettu ryhmän B istunnon alkuosasta, jossa ryhmä vaihtaa kuulumisiaan. Tässä kat- 
kelmassa Mikko on juuri kertonut kuulumisiaan, ja miespuolinen kuntouttaja (MK) kysyy Mikolta, tahtooko tämä kertoa vielä muuta (rivi 04). Mikko vastaa MK:n kysymykseen pitkähköllä vuorolla (rivit 05-09).

\section{Esimerkki 2. (autismi.suomi.2010)}

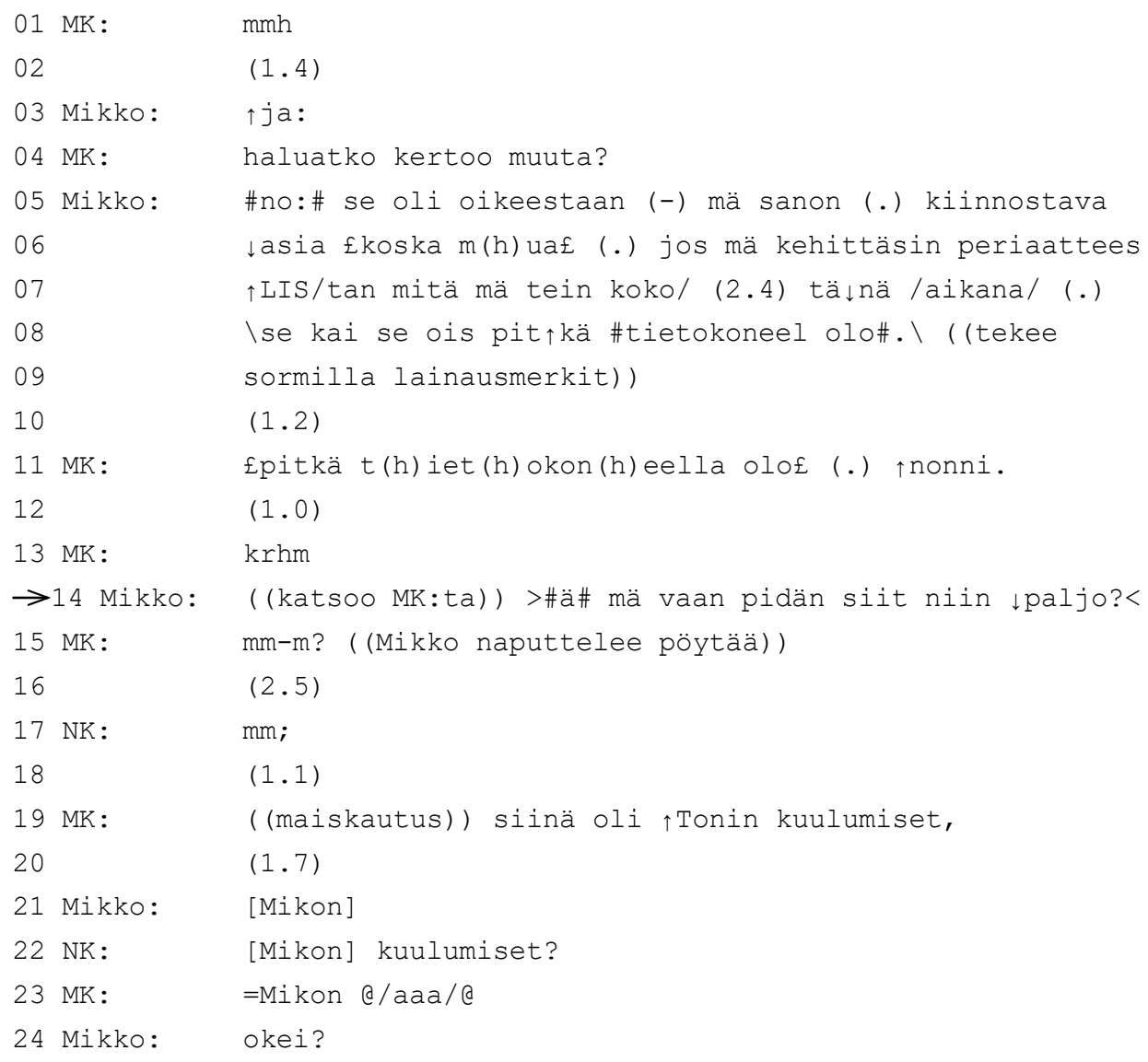

Mikko reagoi tähän kertoen viettäneensä paljon aikaa tietokoneen äärellä (rivit 05-09). Mikon vuoro sisältää puheen epäsujuvuutta, kuten keskeytetty)ä lauserakenteita (rivi 05: 'no: se oli oikeestaan'; rivit 05-06: 'kiinnostava asia koska $\mathrm{m}(\mathrm{h})$ ua') (Wiklund \& Laakso, 2019). Lisäksi lukuisat prosodiset muutokset kuten nariseva ääni (rivi 05: 'no'; rivi 08: 'tietokoneel olo'), mikrotauot (rivit 05, 06 ja 07), sävelkorkeuden muutokset sanojen alussa ja keskellä (rivi 06: 'asia'; rivi 07: 'listan', 'tänä; rivi 08: 'pitkä), voimakas painotus (rivi 05: 'kiinnostava'; rivi 07: 'tänä) ja äänen voimakkuuden nousu (rivi 07: 'listan') luovat vuoroon vaikutelmaa epäsujuvuudesta ja "epätasaisuudesta". Narisevalla äänenlaadulla tuotettu jakso vuoron lopussa (rivi 08) ilmaisee tässäkin vuoron päättymistä (Ogden, 2004). 
Mikko hymyilee ja naurahtaa hiukan sanoessaan 'koska m(h)ua' (rivi 06), ja lopuksi hän piirtää sormilla lainausmerkit sanoessaan 'pitkä tietokoneel olo' (rivi 08). Oletettavasti näistä piirteistä johtuen $\mathrm{MK}$ reagoi Mikon vuoroon tuottamalla hymyillen naurunsekaisen vuoron 'pitkä $\mathrm{t}(\mathrm{h})$ iet(h)okon(h)eella olo nonni' (rivi 11), jossa hän toistaa "lainausmerkkien sisällä tuotetun jakson” Mikon vuoron lopusta. MK:n vuoro päättyy partikkeliin 'nonni' (rivi 11), joka ilmaisee MK:n asennoitumista suhteessa Mikon vuoroon. Hän kuittaa ja hyväksyy Mikon sanoman eikä kommentoi sitä mitenkään. 'Nonni' ilmaisee kuitenkin analyysiemme mukaan tässä tietynlaista "no niinpäs teit; enpäs kommentoi" -tyyppistä asennoitumista, joka kuitenkin välitetään pilke silmäkulmassa, mitä puolestaan osoittavat ei-kielelliset piirteet kuten nauru ja hymy. 'Nonni'-sanan päättyminen laskevaan sävelkulkuun korostaa edellä kuvattua sävyä - ts. sitä, että MK:n ei ole tarkoitus kommentoida sanottua mitenkään mutta että hän kuittaa sen kuulluksi ja hyväksytyksi keskustelun kontribuutioksi.

Kukaan ei ota puheenvuoroa heti MK:n vuoron jälkeen, vaan syntyy tauko (rivi 12). Tämän jälkeen MK tuottaa 'krhm'-äänähdyksen, jolla hän vahvistaa sitä jo edellisen vuoron lopussa olevaa implikaatiota, että ei itse aio jatkaa puhumista. Mikko katsoo MK:ta ja lisää aiemmin sanomaansa ’ä mä vaan pidän siit niin paljo' (rivi 14). Tämä lisäys ilmaisee, että Mikko on tulkinnut MK:n edeltävän vuoron jollain tavalla aiemmin sanomaansa haastavana. Ts. Mikko tuntee itsensä selontekovelvolliseksi ja lisää vuoron, jossa selittää tekemisiensä motiivia. Vuoron lopussa esiintyvä sana 'paljo' on tuotettu siten, että sen ensimmäinen tavu on voimakkaasti painotettu mutta kuitenkin tuotettu ympäristöä matalammalta, kun taas sanan lopussa on intonaation nousu. Koko vuoro on tuotettu kiihdytetyllä puhenopeudella, mikä myös viittaa tarpeeseen antaa selonteko suhteessa aiemmin sanottuun. Vuoron lopussa (rivillä 14) esiintyvä intonaation nousu implikoi tässä, että puhuja kutsuu puhekumppaniensa reaktiota (Routarinne 2003, s. 170), ts. poika hakee muilta hyväksyntää sanomalleen.

MK reagoi Mikon vuoroon nousevaan intonaatioon päättyvällä partikkelivuorolla 'mm-m' (rivi 15). Onkin tavallista, että lausumanloppuiset intonaation nousut johtavat puhekumppanin tuottamaan minimipalautteeseen, jonka avulla puhekumppani merkitsee itsensä sanotun vastaanottajaksi (Ogden \& Routarinne, 2005, s. 173). Tässäkin MK merkitsee itsensä sanotun vastaanottajaksi ja ilmaisee siis olevansa kuulolla (ISK, 2004, § 798). Hän ei kuitenkaan suoranaisesti ilmaise hyväksyntää, jota Mikko kaiketi olisi vuorollaan hakenut. Intonaation loppunousu dialogipartikkelin lopussa implikoi sitä, että MK antaa Mikolle vielä tilaa jatkaa puhumista. Mikko ei kuitenkaan enää ota puheenvuoroa vaan naputtelee pöytää. Seuraa pitkähkö (2,5 sek) tauko (rivi 16), jonka jälkeen NK tuottaa partikkelin 'mm' lievästi laskevalla intonaatiolla (rivi 17). Tämän jälkeen seuraa jälleen tauko (rivi 18), jonka jälkeen $\mathrm{MK}$ tuottaa keskusteluvaiheen päättävän vuoron maiskautuksen jälkeen: 'siinä oli Tonin kuulumiset' (rivi 19). MK erehtyy kuitenkin pojan nimestä, mistä seuraa korjaussekvenssi.

Esimerkkikatkelma osoittaa, että Mikko osaa käyttää prosodisia keinoja vuorovaikutuksellisena resurssina: hän käyttää narisevaa ääntä vuoron päättymisen merkkinä sekä kutsuu puhekumppaniensa reaktiota - tarkemmin sanottuna hakee hyväksyntää - intonaation loppunousun avulla. Lisäksi hän osaa tulkita oikein MK:n tuottaman 'nonni'partikkelin välittämän asenteen. Tämä on pääteltävissä Mikon selontekotyyppisestä reaktiosta suhteessa MK:n vuoroon. 


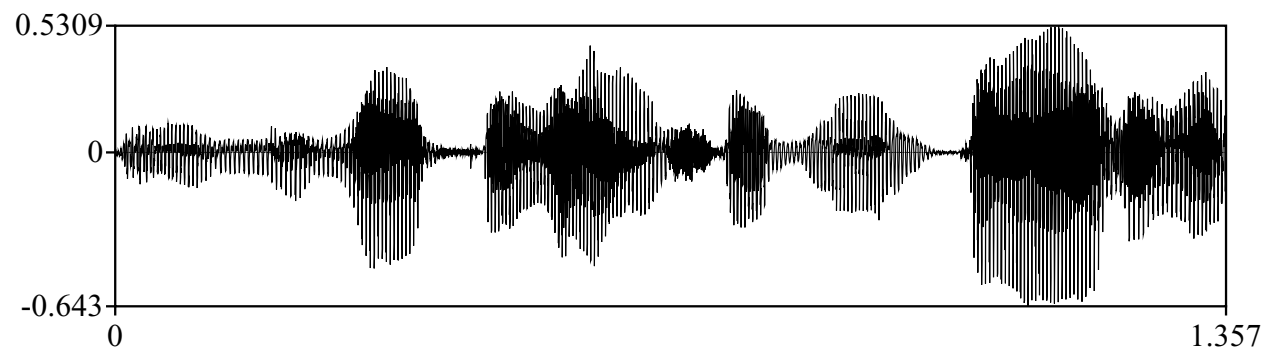

Time (s)

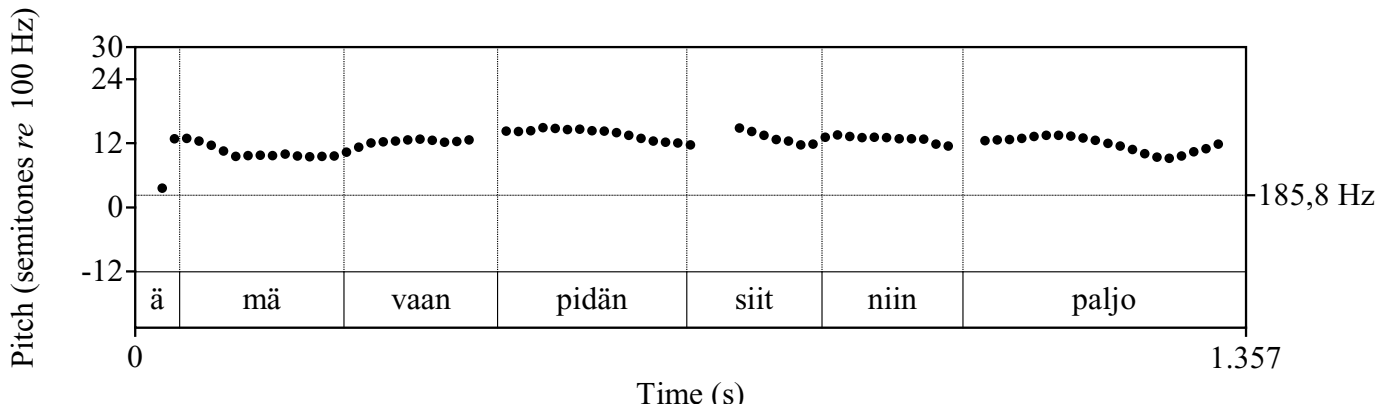

Time (s)

KUVIO 2: Perustaajuus- eli fo-käyrä Mikon kerrontavuoron aikana (esimerkki 2).

Kuvio 2 havainnollistaa sävelkulun muutoksia Mikon vuoron aikana (rivi 14). Perustajuuden keskiarvo lausuman tuottamisen aikana on $202 \mathrm{~Hz}$. Minimisävelkorkeus $\left(f_{0}\right)$ on $170 \mathrm{~Hz}$, ja maksimisävelkorkeus on 237 $\mathrm{Hz}$ (alun muusta käyrästä poikkeava arvo on narinaa). Kuten kuvio 2 osoittaa, vuoron lopussa esiintyy viimeisen tavun [jo] aikana sävelkulun nousu, jonka suuruus on 3,1 puolisävelaskelta. Nousu on siis riittävän suuri luodakseen selvän kuulohavainnon nousevasta intonaatiosta ja johtaakseen täten vastaanottajan minimipalautereaktioon (rivi 15).

\subsection{Kysymyspubeenvuoro ilman nousevaa intonaatiota}

Kolmas esimerkki havainnollistaa tilannetta, jossa autismikirjon poika tuottaa kysymyspuheenvuoron ilman nousevaa intonaatiota (rivi 12). Esimerkki on otettu ryhmän $B$ istunnon alkuosasta, jossa ryhmä vaihtaa kuulumisia. Heikki on juuri kertonut kuulumisiaan mm. hiljattain menneeseen jouluun liittyen, ja nyt on aika esittää hänelle kysymyksiä. 
Esimerkki 3. (autismi.suomi.2010)

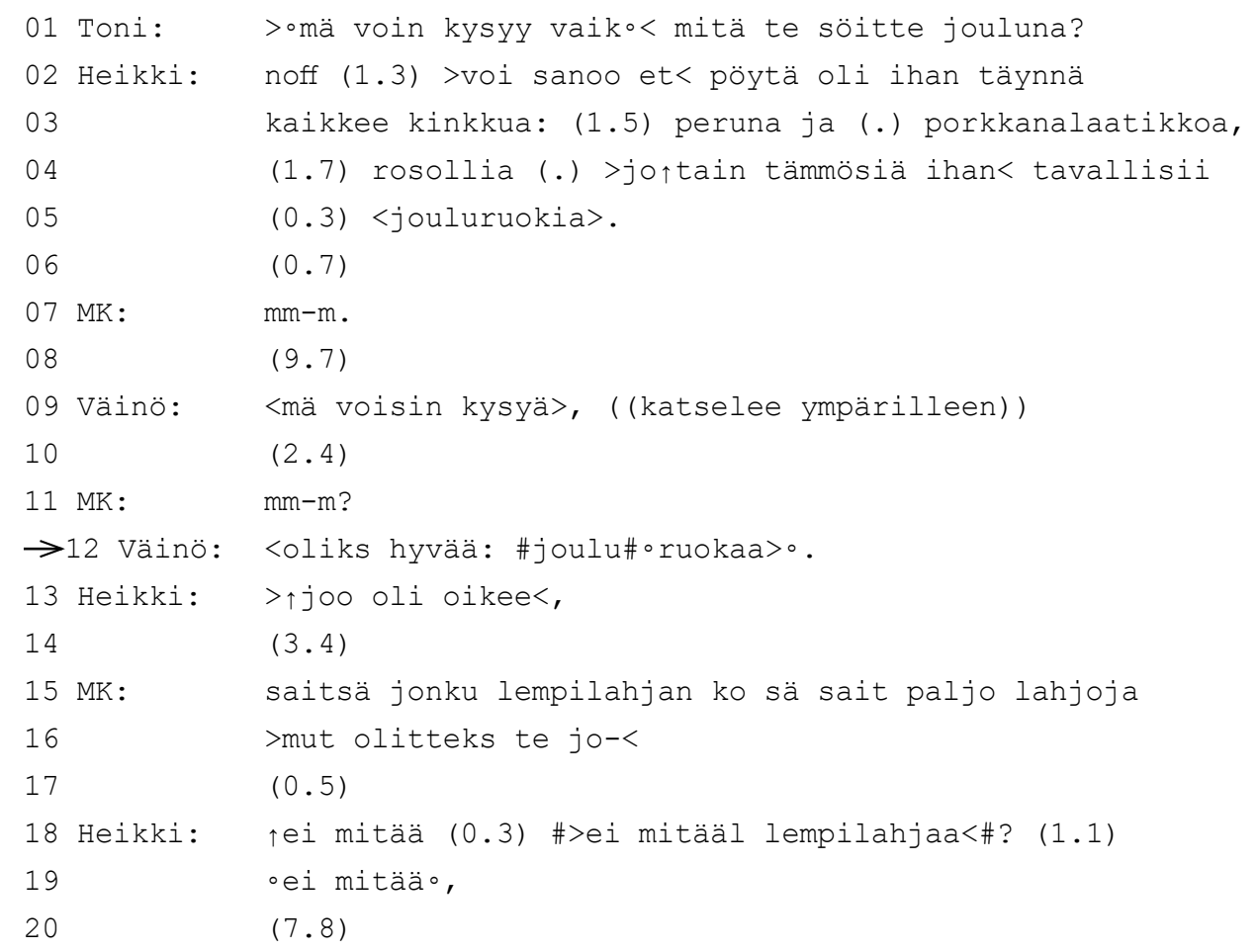

Ensin Toni tarjoutuu esittämään kysymyksen ja kysyykin saman tien (rivi 01). Tonin kysymys päättyy nousevaan intonaatioon. Heikki vastaa Tonin esittämään kysymykseen (rivit 02-05). Heikin vastaus alkaa 'no'-lausumapartikkelilla, joka ilmaisee tässä puhujan siirtymää kerronnasta vastaamiseen sekä mahdollisesti odotuksenvastaisuutta (ISK, 2004, § 1036). Odotuksenvastaisuuteen viittaavat se, että 'no'-partikkeliin liittyy tässä'ff'-äännähdys, ja sitä seuraa 1,3 sekuntia pitkä tauko. Vaikka Tonin kysymys liittyykin aiheeseen, Heikkiä saattaa yllättää se, että häneltä kysytään ruoasta. Tauon jälkeen Heikki kiihdyttää puhenopeuttaan ('voi sanoo et', rivi 02) ja jatkaa sitten vuoroaan alkamalla luetella erilaisia jouluruokia. Sanan 'kinkkua' (rivi 03) ensimmäinen tavu on painotettu erityisen voimakkaasti, ja sanan loppu on pidennetty. Sanaa seuraa 1,5 sekuntia pitkä tauko, joka yhdessä äänteenvenytyksen kanssa ilmaissee tässä epäröintiä, ts. puhuja joutuu miettimään, mitä muuta joulupöydässä olikaan tarjolla (Lehtinen, 2006). Pitkät tauot ovat tosin yleisesti ottaenkin tyypillisiä tälle puhujalle koko aineistossamme. Myös sanan 'porkkanalaatikkoa' jälkeen (rivi 04) esiintyy pitkä, 1,7 sekuntia pitkä tauko. Vuoron viimeinen sana, 'jouluruokia' (rivi 05), on tuotettu hidastetulla puhenopeudella, ja se päättyy laskevaan intonaatioon. Täten Heikin tuottama prosodia ilmaisee selvästi vuoron päättymistä.

Pienen tauon jälkeen MK reagoi Heikin vuoroon dialogipartikkelilla 'mm-m' (rivi 07), joka on tuotettu laskevalla intonaatiolla. Partikkelin avulla MK ilmaisee olevansa kuu- 
lolla (ISK, 2004, § 798). Laskeva intonaatio viittaa siihen, että hän ei odota Heikin enää jatkavan puhumista. MK:n vuoroa seuraa pitkä, peräti 9,7 sekuntia kestävä, tauko (rivi 08). Tämän jälkeen Väinö sanoo hidastetulla puhenopeudella 'mä voisin kysyä' (rivi 09). Kyseessä on esialoitus (pre-start), jolla kyseinen henkilö tarjoutuu seuraavaksi puhujaksi (Sacks, Schegloff \& Jefferson, 1974). On huomionarvoista, että autismikirjon poika tarjoutuu tässä spontaanisti ottamaan puheenvuoron keskustelussa esiintyneen pitkä tauon jälkeen. Esialoituksen tuottaminen pitkän tauon jälkeen on erityisen relevanttia vuorovaikutuksellisesti (verrattuna puheenvuoron ottamiseen ilman esialoitusta), joten Väinö osoittaa tässä huomattavaa vuorovaikutuksellista taitoa. Lisäksi Väinö jää odottamaan, että jompikumpi kuntouttajista reagoisi hänen esialoitukseensa. Seuraa 2,4 sekuntia pitkä tauko, jonka aikana Väinö katselee ympärilleen ja hakee katsekontaktia muihin osallistujiin hakien hyväksyntää esialoitukselleen (rivi 10). MK tuottaa nousevaan intonaatioon päättyvän dialogipartikkelin 'mm-m' (rivi 11), jolla hän hyväksyy Väinön esialoituksen ja siis osoittaa tämän seuraavaksi puhujaksi.

Väinö ottaa puheenvuoron sanomalla hidastetulla puhenopeudella 'oliks hyvää jouluruokaa' (rivi 12). On huomionarvoista, että Väinö odottaa kuntouttajan hyväksyntää ennen kuin ottaa puheenvuoron esialoituksensa jälkeen. Hän myös aktiivisesti hakee katsekontaktia kuntouttajiin tauon aikana. Tässäkin mielessä Väinö osoittaa tässä katkelmassa huomattavaa vuorovaikutuksellista taidokkuutta. Hidas puhenopeus Väinön vuorossa on kyseiselle pojalle tyypillinen prosodinen piirre, joka esiintyy hänen puheessaan suuren osan ajasta. Sana 'hyvää' on pidennetty (rivi 12). Äänteenvenytyksellä lienee tässä sanottua korostava tehtävä. Lisäksi se ennakoi vuoron päättymistä. Vuoron viimeinen sana, 'jouluruokaa' (rivi 12) on tuotettu siten, että sanan ensimmäinen osa on tuotettu narisevalla äänellä ja sanan jälkimmäinen osa hiljaisella äänellä. Vuoro päättyy laskevaan intonaatioon. Nämä piirteet ilmaisevat tyypillisesti päättyvyyttä suomessa (Anttila, 2008; Ogden, 2004), kuten jo ylempänä on todettu. Väinön tuottama esialoitus saa aikaan sen, että pojan seuraava vuoro tulee olemaan kysymys (rivi 09). Väinön lausuman (rivi 12) merkitsee myös selvästi kysymykseksi sen ensimmäisen sanan lopussa esiintyvä partikkeli -kO (tässä muodossa '-ks') (ISK, 2004, $\S 802)$. Heikki tulkitseekin Väinön vuoron kysymyksesi ja vastaa siihen saman tien 'joo oli oikee' nopealla puhenopeudella (rivi 13). Väinön vastauksen ensimmäinen sana, 'joo', on voimakkaasti painotettu ja tuotettu huomattavan korkealta säveltasolta. Heikki käyttää siis tässäkin prosodiaa korostuskeinona. Tämän jälkeen seuraa 3,4 sekuntia pitkä tauko (rivi 14), jonka jälkeen MK esittää Heikille kysymyksen (rivit 15-16). Heikki vastaa kysymykseen (rivit 18-19) pienen tauon jälkeen, vaikka MK:n vuoro päättyy hieman epäselvästi (rivi 16). Heikki korostaa jälleen prosodian avulla vastauksensa ensimmäistä sanaa, 'ei' (rivi 18). Lisäksi hän toistaa 'ei mitää' -jakson kolme kertaa vuoronsa aikana. Toisto toimii tässä myös korostuskeinona. Viimeinen 'ei mitää' -jakso on tuotettu hiljaisella äänellä, mikä ilmaisee vuoron päättymisen lähestymistä. Vuoro päättyykin tähän ilmaisuun, ja keskustelussa seuraa pitkä, 7,8 sekuntia kestävä, tauko (rivi 20).

Kuten jo aiemmat samaan aineistoon perustuvat tutkimukset ovat osoittaneet, tämäkin esimerkki antaa viitteitä siitä, että autismikirjon varhaisnuoret osaavat tulkita oikein dialogipartikkelien ja prosodisten piirteiden yhdistelmien vuorovaikutuksellisia tehtäviä (Wiklund, 2012; Wiklund \& Stevanovic, 2018; Wiklund \& Vainio, 2019). Lisäksi tässäkin katkelmassa autismikirjon 
pojat käyttävät prosodisia piirteitä puheen korostuskeinoina sekä ilmaisevat päättyvyyttä niiden avulla. Katkelma osoittaa, että tutkitut autismikirjon pojat osaavat esittää käsiteltävän aiheen kannalta relevantteja kysymyksiä ja vastata niihin. Yksi heistä osaa myös tuottaa esialoituksen ja odottaa keskustelua ohjaavalta henkilöltä reaktiota siihen. Tämä tukee Kremer-Sadlikin (2001, 2004) tuloksia, joiden mukaan autismikirjon lapset osaavat osallistua kysymys-vastaus -vieruspareihin suhteellisen kompetentisti.

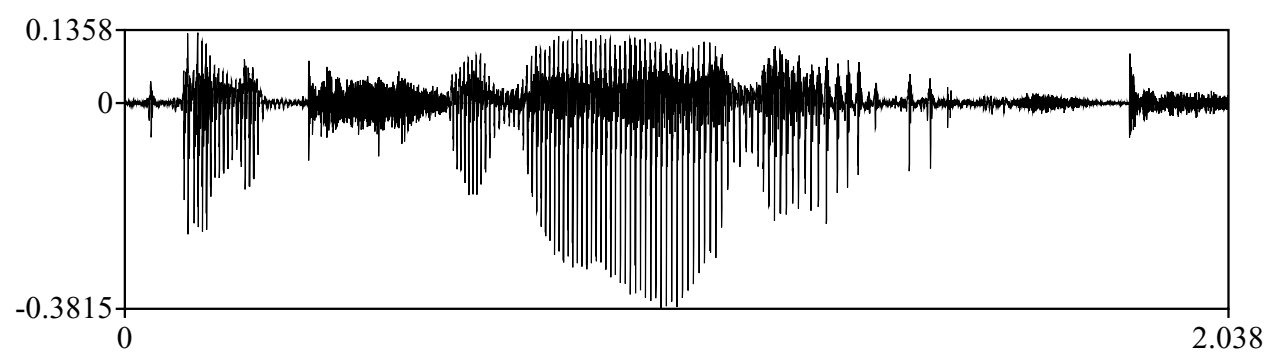

Time (s)

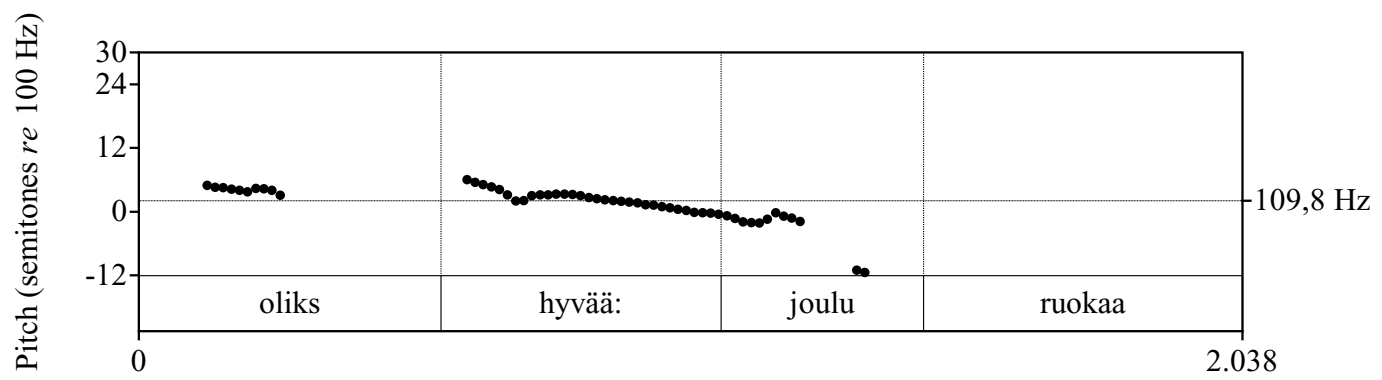

Time (s)

KUVIO 3: Perustaajuus- eli fo-käyrä Väinön kysymysvuoron aikana (esimerkki 3).

Kuvio 3 havainnollistaa sävelkulun muutoksia Väinön kysymysvuoron aikana (rivi 12). Perustaajuuden keskiarvo kyseisen vuoron aikana on $100 \mathrm{~Hz}$. Minimisävelkorkeus on $80 \mathrm{~Hz}$, ja maksimisävelkorkeus on $141 \mathrm{~Hz}$. Kuten kuvio 3 osoittaa, puhujan sävelkulku laskee huomattavasti lausuman lopussa, yhdyssanan 'jouluruokaa' aikana. 'Joulu'-osan lyhyt perustaajuuskäyrän pätkä matalalla tasolla on narina-artefakti; sitä vastaa vain yksi nariseva pulssi, joten perustaajuutta ei ole. Näin ollen minimi ilmauksessa on n. $80 \mathrm{~Hz}$. Narina tulee kuitenkin voimakkaasta laskusta jo joulun aikana. Yhdyssanan jälkimmäinen osa, 'ruokaa', on kokonaan soinniton, joten Praat ei löydä perustaajuuskäyrää sen tuottamisen aikana. Kuulonvarainen vaikutelma intonaatiosta on kuitenkin voimakkaasti laskeva. Intonaation laskun lisäksi lausuman lopussa esiintyy myös muita vuoron päättymistä ennakoivia prosodisia piirteitä: sanan 'hyvää lopussa esiintyy tavun venytys, 'joulu-' on tuotettu narisevalla äänellä ja 'ruokaa' puolestaan ympäristöä huomattavasti hiljaisemmalla äänellä (Anttila, 2008; Ogden, 2004). Heikki tulkitseekin Väinön kysymysvuoron päättyneeksi ja tuottaa siihen välittömästi vastauksen (rivi 13). 


\subsection{Kysymyspubeenvuoro, joka päättyy nousevaan intonaatioon}

Viimeinen esimerkki havainnollistaa kysymyspuheenvuoroja, jotka päättyvät nousevaan intonaatioon. Tällaisia vuoroja on katkelmassa kolme (rivit 04, 14 ja 24). Lisäksi katkelma sisältää muita nousevaan intonaatioon päättyviä vuoroja. Esimerkki on otettu ryhmän B istunnon alkuosasta. Mikko on juuri kertonut kuulumisiaan, ja Väinö ilmoittaa voivansa aloittaa kysymysten esittämisen (rivi 01). Kyseessä on esimerkin 3 tapaan esialoitus, jolla Väinö ehdottaa itseään seuraavaksi puhujaksi. Vuoro päättyy lievästi nousevaan intonaatioon.

\section{Esimerkki 4. (autismi.suomi.2010)}

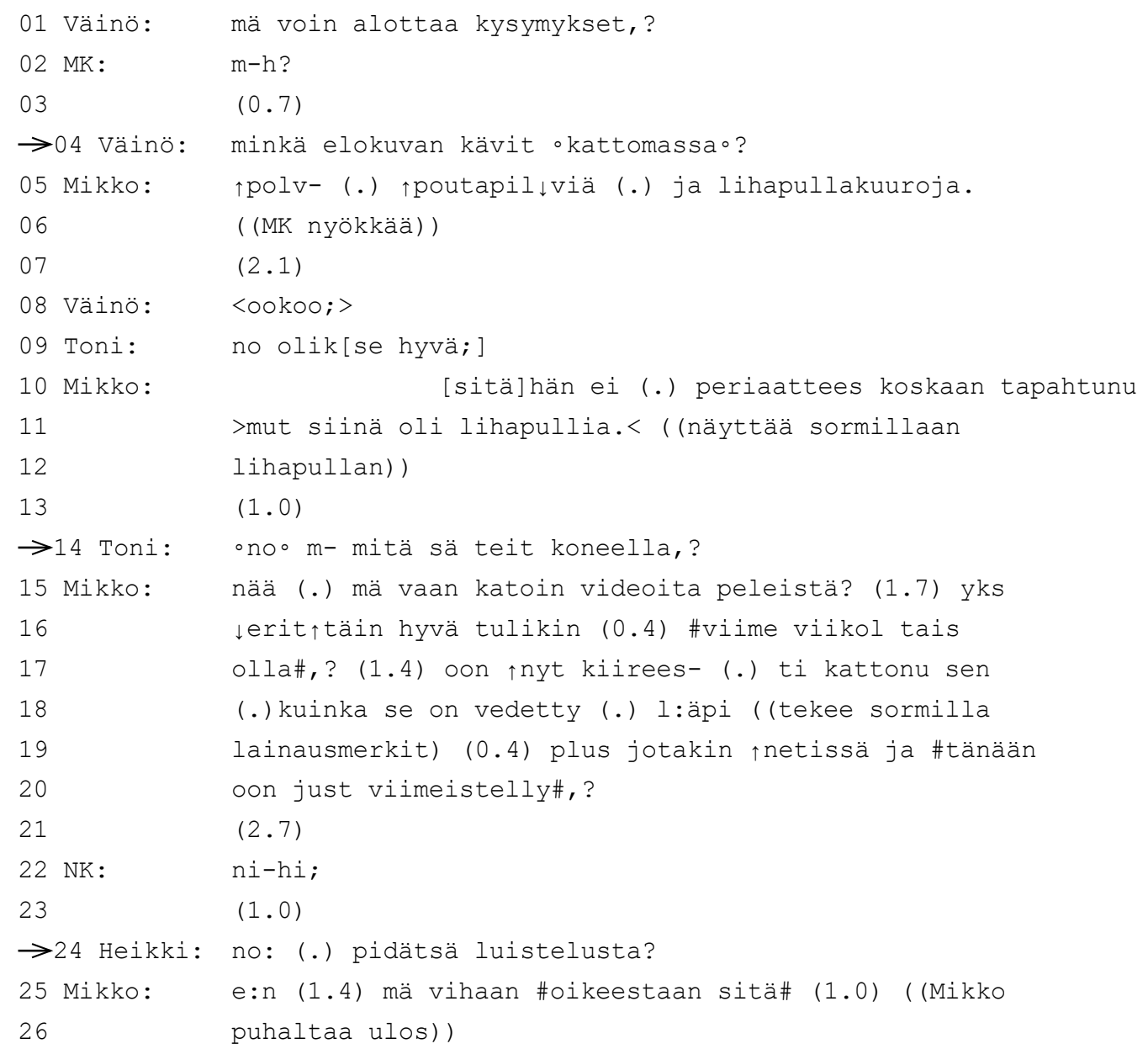


MK reagoi Väinön esialoitukseen nousevaan intonaatioon päättyvällä partikkelivuorolla 'm-h' (rivi 02). Nouseva intonaatio esialoituksen lopussa ilmaisee, että Väinö odottaa keskustelua ohjaavan kuntouttajan reagoivan vuoroonsa. Se siis ilmaisee puhujan hakevan vastaanottajan reaktiota, mikä on tyypillistä intonaation loppunousuille (Routarinne, 2003, s. 170). Lisäksi loppunousu saattaa tässä yhteydessä liittyä tietynlaisen jatkuvuuden ilmaisemiseen: Väinö hakee loppunousulla kuntouttajan reaktiota mutta myös ilmaisee, että aikoo itse jatkaa puhumista hakemansa reaktion jälkeen.

Tauon jälkeen Väinö esittää varsinaisen kysymyksensä, 'minkä elokuvan kävit kattomassa' (rivi 04). Väinön kysymyksen viimeinen sana, 'kattomassa', on lausuttu ympäristöä hiljaisemmalla äänellä, mikä implikoi vuoron päättymistä. Kysymys kuitenkin päättyy nousevaan intonaatioon. Nouseva intonaatio voi liittyä siihen, että kysymys esiintyy eräänlaisessa "kysymysjonossa”. Ts. puhujan tiedossa on, että kukin poika tulee kysymään yhden kysymyksen, ja hän on itse ensimmäinen. Toisaalta Väinö tuottaa esimerkissä 3 kysymyksen samaan tapaan "kysymysjonossa", ja silloin intonaatio on laskeva. Ero on kuitenkin se, että esimerkissä 3 Väinö ei ole ensimmäinen kysyjä, kuten tässä esimerkissä.

On myös mahdollista, että vaikka suomessa lausumanloppuinen intonaation nousu ei ole kieliopillistunut kysymyksen merkiksi (Hirvonen, 1970; Iivonen, 1978, 1998; Kallioinen, 1968; Routarinne, 2003, s. 179-183), nouseva intonaatio kuitenkin vahvistaa interrogatiivisuutta ja vastaanottajaan vetoamista tietynlaisissa yhteyksissä spontaanissa vuorovaikutuksessa. Tällaisia yhteyksiä voisivat olla esimerkiksi tämän katkelman kaltainen esiintymisyhteys, jossa on kyse institutionaalisesta tilanteesta, jossa kysymyksen esittäminen on tilanteen ennalta määrittämä toiminto. Tällöin puhuja voi tavallaan nousevan into- naation avulla korostaa sitä, että hän toimii tilanteen edellyttämällä tavalla ja esittää kysymyksen omalla vuorollaan. On kuitenkin muistettava, että aineistossamme vain $46 \%$ poikien tuottamista kysymyksistä päättyy nousevaan intonaatioon (ks. 3.1). Kyse ei siis ole systemaattisesti tai edes dominoivasti esiintyvästä ilmiöstä. Intonaation nousuun päättyvien kysymysten osuus (46\%) aineistossamme on kuitenkin mielestämme melko suuri, kun ottaa huomioon, että kaikki kysymykset eivät pääty intonaation nousuun edes esimerkiksi ranskassa (Delais-Roussarie ym., 2015).

Mikko vastaa Väinön kysymykseen 'polvpoutapilviä ja lihapullakuuroja' (rivi 05). Vastaus on prosodisesti mielenkiintoinen, koska vuoroon sisältyy suuria intonaation vaihteluita: ensin keskeytetyn sanan ensimmäinen ( $j a$ ainoa) tavu 'polv-' on lausuttu huomattavan korkealta säveltasolta. Sitä seuraa mikrotauko, jonka jälkeen 'poutapilviä'-sanan ensimmäinen tavu on lausuttu taas huomattavan korkealta. Yhdyssanan jälkimmäisen osan loppu ('-viä) on kuitenkin lausuttu huomattavan matalalta. Vuoroon syntyy tämän vuoksi lähestulkoon laulua muistuttava intonaatio. Tällaiset suuret intonaation vaihtelut ovat tyypillisiä tälle puhujalle koko tutkitussa aineistossa (Wiklund \& Vainio, 2019). MK reagoi Mikon vuoroon nyökkäämällä (rivi 06), minkä jälkeen keskustelussa seuraa 2,1 sekuntia pitkä tauko (rivi 07). Tämän jälkeen Väinö sanoo 'ookoo' hitaalla puhenopeudella ja kuittaa täten Mikon vuoron kuulluksi ja ymmärretyksi (rivi 08).

Väinön kuittauksen jälkeen Toni kysyy spontaanin jatkokysymyksen suhteessa Väinön esittämään kysymykseen 'no oliks se hyvä' (rivi 09). Tämä kysymys päättyy lievästi laskevaan intonaatioon. Tässä yhteydessä lievästi laskeva intonaatio voi liittyä siihen, että kyseessä on jatkokysymys. Toni ei siis esitä kysymystään "kysymysjonossa" varsinaisena 
omana kysymyksenään omalla vuorollaan vaan spontaanina jatkokysymyksenä suhteessa Väinön esittämään kysymykseen. Mikko alkaa puhua Tonin päälle antaen lisätietoa näkemästään elokuvasta (rivit 10-11). Hän ei siis vastaa Tonille vaan lisää selvennyksen omaan aiempaan vuoroonsa (rivi 05).

Sekunnin tauon jälkeen Toni esittää oman varsinaisen kysymyksensä: 'no m- mitä sä teit koneella' (rivi 14). Tämä kysymys päättyy lievästi nousevaan intonaatioon. Vuoro alkaa 'no'-lausumapartikkelilla, joka ilmaisee tässä kahdenlaista siirtymää (ISK, 2004, § 1036): yhtäältä topikaalista siirtymää elokuvasta tietokoneeseen, toisaalta toiminnallista siirtymää Väinön esittämästä kysymyksestä ja siihen liittyvästä jatkokeskustelusta Tonin kysymysvuoroon. Nouseva intonaatio voi siis tässä liittyä kysymyksen esiintymiseen institutionaalisen tilanteen määrittelemässä kohdassa (ts. "kysymysjonossa" yhtenä kysymyksenä). Toisaalta kyse voi olla myös prosodian "kierrättämisestä". Ts. puhuja asettaa kysymysvuoronsa osaksi "kysymysjonoa" nimenomaan kierrättämällä Väinön aiemmin omassa kysymyksessään käyttämää nousevaa intonaatiota (vrt. esim. Szczepek Reed, 2009).

Mikko antaa pitkähkön vastauksen Tonin esittämään kysymykseen (rivit 15-20). Tähänkin vuoroon sisältyy useita suuria sävelkulun nousuja ja laskuja sanojen alussa ja sisällä (rivi 16: 'erittäin'; rivi 17: 'nyt'; rivi 19: 'netissä). Lisäksi vuoroon sisältyy useita lausumanloppuisia intonaation nousuja (rivit 15, 17, 20). Narisevaa ääntä esiintyy sekä riveillä 16-17 ('viime viikol tais olla') että vuoron lopussa (rivit 19-20: 'tänään oon just viimeistelly'). Joidenkin sanojen alussa on voimakas painotus (rivi 18: 'läpi'; rivi 19: 'netissä; rivi 20: 'viimeistelly'). Mikko käyttää vuorossaan painotusta korostuskeinona ja narisevaa ääntä vuoron päättymistä ilmaisevana prosodisena keinona. Kuitenkin prosodisten muutosten suuri märä samassa vuorossa luo siihen jos- sain määrin epäsujuvan vaikutelman (Wiklund \& Laakso, 2019).

Mikon vuorossa (rivit 15-20) ensimmäinen loppunousuun päättyvä lausuma ('nn mä vaan katoin videoita peleistä, rivi 15) on luonteeltaan orientoiva; se orientoi vastaanottajia siihen, että kerrontalinja jatkuu vielä ja ilmaisee, mihin jatko tulisi suhteuttaa (Routarinne, 2003). Toinen intonaation loppunousuun päättyvä vuoro ('viime viikol tais olla', rivit 16-17) puolestaan antaa taustainformaatiota suhteessa varsinaisiin tapahtumiin (Routarinne, 2003, s. 183-188). Viimeinen intonaation loppunousuun päättyvä lausuma ('ja tänään oon just viimeistelly', rivit 19-20) kutsuu puhekumppanien reaktiota (Routarinne, 2003). Lisäksi viimeinen lausuma on siis tuotettu narisevalla äänellä, mikä implikoi vuoron päättymistä (Ogden, 2004). On huomionarvoista, että Mikko osoittaa toistuvilla lausumanloppuisilla intonaation nousuillaan, että hän ottaa puhekumppaninsa huomioon (Routarinne, 2003, s. 183).

Mikon vuoroa seuraa 2,7 sekuntia pitkä tauko (rivi 21), jonka jälkeen NK kuittaa Mikon vuoron lievästi laskevaan intonaatioon päättyvällä partikkelivuorolla 'ni-hi' (rivi 22). Tämän jälkeen seuraa sekunnin tauko (rivi 23), jonka jälkeen Heikki esittää vuorollaan oman kysymyksensä, 'no pidätsä luistelusta' (rivi 24). Myös Heikin vuoro alkaa siirtymää ilmaisevalla lausumapartikkelilla 'no' (ISK, 2004, \$ 1036) ja päättyy nousevaan intonaatioon. Siirtymä on tässäkin sekä topikaalinen että toiminnallinen, kuten Tonin vuoron tapauksessa (rivi 14). Intonaation nousu kysymyksen lopussa liittynee tässäkin sekä kysymyksen esiintymiseen institutionaalisen tilanteen määrittelemässä "kysymysjonossa" että prosodian kierrättämiseen - ts. siihen, että myös kaksi edeltävää kysyjää ovat päättäneet kysymyksensä nousevaan intonaatioon. Mikko vastaa Heikin kysymykseen 'en mä vihaan oikeestaan sitä (rivi 25) ja puhaltaa ulos 
(rivit 25-26). Vuoron ensimmäinen sana, 'en', on voimakkaasti painotettu, ja sitä seuraa 1,4 sekuntia pitkä tauko. Myös sana 'vihaan' alkaa voimakkaalla painotuksella. Vuoron loppu, 'oikeestaan sitä, on jälleen tuotettu narisevalla äänellä. Mikko siis käyttää tässäkin vuorossaan prosodisia piirteitä sekä korostuskeinoina että vuoron päättymistä ilmaisevina keinoina.

Esimerkin 3 tapaan tämäkin katkelma osoittaa, että aineistomme autismikirjon pojat osaavat esittää käsiteltävän aiheen kannalta relevantteja kysymyksiä ja vastata niihin (Kremer-Sadlikin, 2001, 2004). Yksi pojista osaa myös osoittaa toistuvilla lausumanloppuisilla intonaation nousuillaan, että hän ottaa puhe- kumppaninsa huomioon (Routarinne, 2003, s. 183). Tämä on merkittävää, sillä kuten jo aiemmin on todettu, vastavuoroinen vuorovaikutus ja toisen näkökulman huomioiminen on yleisesti ottaen autismikirjon henkilöille vaikeaa (APA, 2013). Esimerkki myös vahvistaa aiempia tutkimustuloksia, joiden mukaan autismikirjon lapset osaavat tuottaa kerrontasekvenssejä keskustelussa (Solomon, 2001, 2004; Wiklund, 2012). Lisäksi - kuten artikkelimme aiemmat esimerkit - tämäkin katkelma osoittaa, että aineistomme autismikirjon pojat osaavat sekä tuottaa että tulkita oikein vuoron päättymistä ilmaisevia prosodisia piirteitä keskustelussa.
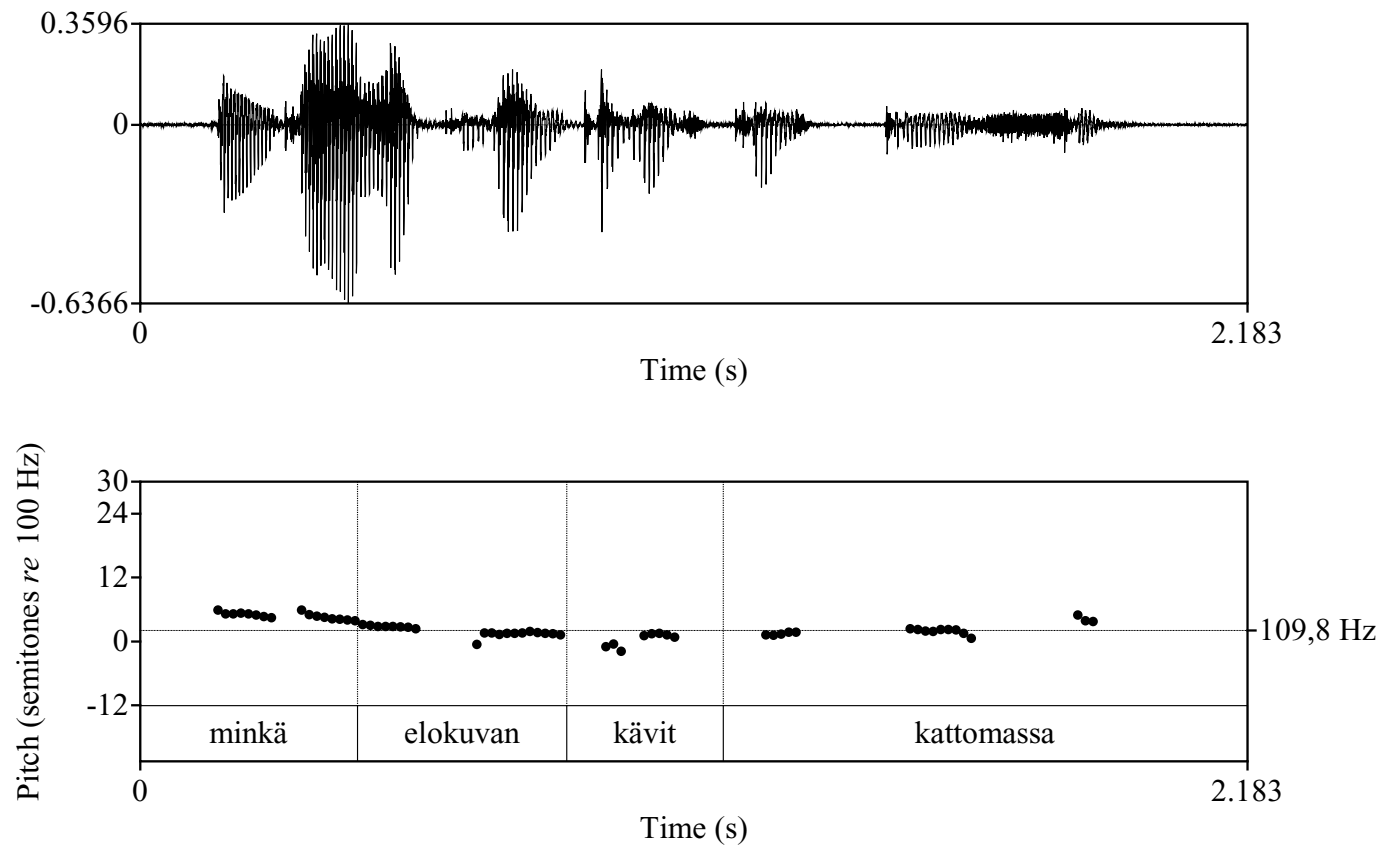

KUVIO 4: Perustaajuus- eli fo-käyrä Väinön kysymysvuoron aikana (esimerkki 4). 
Kuvio 4 havainnollistaa sävelkulun $\left(f_{0}\right)$ muutoksia Väinön kysymysvuoron aikana (rivi 04). Keskimääräinen perustaajuus lausuman aikana on $116 \mathrm{~Hz}$. Minimiperustaajuus on $90 \mathrm{~Hz}$ ja maksimiperustaajuus $141 \mathrm{~Hz}$. Kuten perustaajuuskäyrän muoto osoittaa, sävelkulku lausuman tuottamisen aikana on varsin tasainen. Lausuman lopussa sävelkulku kuitenkin nousee hiukan kahden viimeisen tavun välillä: tavujen [mas] ja [sa] välinen sävelkorkeuden ero on 2,0 puolisävelaskelta. Vaikka nousu on kooltaan pieni, se riittää luomaan kuulohavainnon intonaation loppunoususta. Perustaajuuden muutoksen lisäksi vuoron päättymistä ennakoi tässä se, että kysymyksen viimeinen sana, 'kattomassa', on tuotettu ympäristöä hiljaisemmalla äänellä (Anttila, 2008; Ogden, 2004). Kysymyksen vastaanottaja, Mikko, tulkitseekin Väinön vuoron päättyneeksi ja antaa välittömästi vastauksen hänelle esitettyyn kysymykseen (rivi 05).

\section{LOPUKSI}

Tutkimuksemme päämääränä on ollut vastata seuraaviin tutkimuskysymyksiin: 1) Esiintyykö 11-13-vuotiaiden suomenkielisten autismikirjon poikien kysymys- ja/tai kerrontavuoroissa toistuvasti myös nousevaa intonaatiota spontaanissa institutionaalisessa vuorovaikutuksessa? 2) Jos nousevaa intonaatiota esiintyy, vastaako sen käyttö aiemmassa tutkimuskirjallisuudessa esitettyä käyttöä suomen kielessä? 3) Käyttävätkö tutkittavat henkilöt muita prosodisia piirteitä vuorovaikutuksellisina resursseina?

Ensimmäisen tutkimuskysymyksen osalta tuloksemme osoittavat, että tutkittavien henkilöiden puheessa esiintyy toistuvasti myös nousevaa intonaatiota. Erityisesti kysymyksissä nouseva loppuintonaatio on tavallinen ilmiö aineistossamme. Keskimäärin kaikista poikien puheessa esiintyvistä vuoroista $20 \%$ päättyy nousevaan intonaatioon. Kysymysvuoroista $46 \%$ päättyy intonaation nousuun. Yksilöllinen vaihtelu nousevaan intonaatioon päätyvien vuorojen määrien suhteen on kuitenkin aineistossamme suurta. Toisen tutkimuskysymyksen osalta tuloksemme viittaavat siihen, että tutkimuksen osallistujat osaavat käyttää lausumanloppuista intonaation nousua vuorovaikutuksellisena resurssina. $\mathrm{He}$ osaavat nimittäin mm. kutsua intonaation loppunousun avulla reaktioita muilta osallistujilta sekä ilmaista vastaanottajan huomioonottamista (Routarinne, 2003). He osaavat myös "kierrättää" prosodiaa, ts. toistaa aiemman puhujan tuottamaa vuoron prosodista muotoa. Kolmannen kysymyksen osalta tuloksemme viittaavat siihen, että tutkimamme autismikirjon pojat osaavat sekä tuottaa että tulkita oikein päättyvyyttä ilmaisevia prosodisia piirteitä spontaanissa vuorovaikutuksessa. Toisin sanottuna he osaavat sekä tuottaa että tulkita esimerkiksi laskevaa intonaatiota, narisevaa ääntä sekä hiljaista ääntä vuoron päättymistä ilmaisevina prosodisina vihjeinä (Ogden, 2004). He osaavat myös korostaa sanoja painotuksen ja intonaation muutosten avulla.

Tutkimuksemme autismikirjon pojat vaikuttaisivat pystyvän käyttämään hyväkseen intonaatiota vuorovaikutuksellisena resurssina, vaikka vastavuoroinen vuorovaikutus on yleisesti ottaen autismikirjon henkilöille vaikeaa (APA, 2013). Intonaation käyttöä vuorovaikutuksellisena resurssina voitaisiin kuitenkin mahdollisesti harjoitella enemmänkin autismikirjon lasten ja nuorten kuntoutuksessa. Autismikirjon varhaisnuorilla vaikuttaa nimittäin ainakin tämän tutkimuksen perusteella olevan lähtökohtaisesti edellytykset intonaation vuorovaikutukselliseen käyttöön, joten näitä edellytyksiä voitaisiin tulevaisuudessa vahvistaa aiempaa enemmän tietoisen harjoittelun kautta. 
Havaintomme tukevat aiempia tutkimuksia, joiden mukaan autismikirjon lapset osaavat tuottaa kerrontasekvenssejä keskustelussa (Solomon, 2001, 2004; Wiklund, 2012). Aineistomme sisältää myös kohtia, joissa autismikirjon pojat osaavat käyttää nousevaa intonaatiota kerrontasekvensseissä samaan tapaan kuin Routarinteen (2003) aineiston nuoret tytöt: intonaation nousua voidaan esimerkiksi käyttää orientoivien ja taustainformaatiota antavien lausumien lopussa kerrontaa jäsentävinä keinoina (Routarinne, 2003, s. 183-188).

Lisäksi analyysimme osoittavat, että tutkitut autismikirjon pojat osaavat esittää käsiteltävän aiheen kannalta relevantteja kysymyksiä ja vastata niihin. Tämä tukee Kremer-Sadlikin $(2001,2004)$ tuloksia, joiden mukaan autismikirjon lapset osaavat osallistua kysymys-vastaus -vieruspareihin suhteellisen kompetentisti. Havaintomme tukevat myös niitä aiempia tuloksia, joiden mukaan autismikirjon lapset osaavat tulkita oikein dialogipartikkelien ja prosodisten piirteiden yhdistelmien vuorovaikutuksellisia tehtäviä (Wiklund, 2012; Wiklund \& Stevanovic, 2018; Wiklund \& Vainio, 2019).

Tulevaisuudessa olisi mielenkiintoista tutkia autismikirjon henkilöiden kysymysja kerrontavuorojen prosodiaa eri kielissä. Suomenkielisen aineiston vertailu johonkin toiseen kieleen, jossa intonaation loppunousu on kieliopillistunut kysymyksen merkiksi ja jossa intonaatiojärjestelmä on muutenkin erilainen, olisi erityisen kiinnostavaa. Tällainen vertailukieli voisi olla esimerkiksi ranska, jossa lausumanloppuiset intonaation nousut ovat hyvin yleisiä ja myös osa kielen vakiintunutta intonaatiojärjestelmää (ks. esim. Di Cristo, 1998; Lehtinen, 2010b; Morel \& DanonBoileau, 1998).

\section{Litteroinnissa käytetyt merkit:}

$\begin{array}{ll}\cdot & \begin{array}{l}\text { (prosodisen kokonaisuuden } \\ \text { lopussa) laskeva intonaatio }\end{array} \\ ; & \text { lievästi laskeva intonatio } \\ , ? & \text { tasainen intonaatio } \\ ? & \text { lievästi nouseva intonatio } \\ \downarrow & \text { nouseva intonaatio } \\ \uparrow & \text { ympäristöä matalammalta } \\ \uparrow & \text { tuotettu jakso } \\ & \text { ympäristöä korkeammalta } \\ & \text { tuotettu jakso }\end{array}$

sika painotus

$>$ tosi< nopeutettu puhejakso

$<$ paitsi> hidastettu puhejakso

joo:

MITÄ huutoa tai kovaäänistä puhetta

.hhh sisäänhengitys: yksi h-kirjain vastaa 0,1 sekuntia

hhh uloshengitys

joo sisäänhengittäen tuotettu sana

@just@ äänenlaadun muutos

$\mathrm{k}(\mathrm{h})$ iva nauraen tuotettu puhejakso

£niimpä£ hymyillen tuotettu puhejakso

\#ai\# narisevalla äänellä tuotettu puhejakso

oniio ympäristöä hiljaisemmalla äänellä tuotettu puhejakso päällekkäispuhunta alkaa päällekkäispuhunta päättyy (.) mikrotauko, alle 0,2 sekuntia (0.6) tauko, pituus sekunteina (lapset) epäselvästi kuultu puhejakso tai puhuja

(--) puhejaksosta tai puhujan henkilöllisyydestä ei ole saatu selvää

((outo piippaus)) litteroijan kommentteja ja selityksiä; eleet

$\rightarrow \quad$ relevantti rivi litteraatissa 


\section{LÄHTEET}

American Psychiatric Association (APA) (2000). Diagnostic and Statistical Manual of Mental Disorders, $4^{\text {th }}$ Edition (DSM-IV). Washington, DC: APA.

American Psychiatric Association (APA) (2013). Diagnostic and Statistical Manual of Mental Disorders, $5^{\text {th }}$ Edition (DSM-V). Washington, DC: APA.

Anttila, H. (2008). The effect of interrogative function on intonation in spontaneous and read Finnish. Pro gradu -tutkielma. Helsinki: Helsingin yliopisto.

Anttila, H. (2009). Interrogative intonation in spontaneous Finnish. Teoksessa V. de Silva \& R. Ullakonoja (toim.), Phonetics of Russian and Finnish. General Description of Phonetic Systems. Experimental Studies on Spontaneous and Readaloud Speech, (s. 167-176). Frankfurt am Main: Peter Lang.

Baltaxe, C. (1984). Use of contrastive stress in normal, aphasic, and autistic children. Journal of Speech and Hearing Research, 27, 97-105.

Baltaxe, C. \& Simmons, J. (1985). Prosodic development in normal and autistic children. Teoksessa E. Schopler \& G. Mesibov (toim.), Communication problems in autism, (s. 95125). New York: Plenum Press.

Baltaxe, C. \& Simmons, J. (1992). A comparison of language issues in high-functioning autism and related disorders with onset in children and adolescence. Teoksessa E. Schopler \& G. Mesibov (toim.), High-functioning individuals with autism, (s. 210-225). New York: Plenum Press.

Boersma, P. \& Weenink, D. (2019): Praat: doing phonetics by computer. Tietokoneohjelma. Haettu 16.4.2019 osoitteesta http://www. praat.org/

Couper-Kuhlen, E. (2000). Prosody. Teoksessa J. Verschueren, J.-O. Östman, \& C. Bulcaen (toim.), Handbook of pragmatics, (s. 1-19). Amsterdam / Philadelphia: John Benjamins Publishing Company.

Couper-Kuhlen, E. (2004). Prosody and sequence organization in English conversation. The case of new beginnings. Teoksessa E. CouperKuhlen \& C. E. Ford (toim.), Sound patterns in interaction, (s. 335-376). Amsterdam / Philadelphia: John Benjamins Publishing Company.
Crystal, D. (1969). Prosodic systems and intonation in English. Cambridge: Cambridge University Press.

Crystal, D. (1980). A first dictionary of linguistics and phonetics. London: Deutsch.

Damico, J. S. \& Nelson, R. L. (2005). Interpreting problematic behavior: Systematic compensatory adaptations as emergent phenomena in autism. Clinical Linguistics \& Phonetics, 19, 405-417.

Delais-Roussarie, E., Post, B., Avanzi, M., Buthke, C., Di Cristo, A., Feldhausen, I., Jun, S.-A., Martin, Ph., Meisenburg, T., Rialland, A., Sichel-Bazin, R. \& Yoo, H.-Y. (2015): Intonational Phonology of French: Developing a ToBI system for French. Teoksessa S. Frota \& P. Prieto (toim.), Intonation in Romance. Oxford: Oxford University Press. DOI:10.1093 cprof:oso/9780199685332.003.0003

Di Cristo, A. (1998). Intonation in French. Teoksessa D. Hirst \& A. Di Cristo (toim), Intonation Systems: A Survey of Twenty Languages, (s. 195-218). Cambridge: Cambridge University Press.

Diehl, J.J., Watson, D., Bennetto, L., McDonough, J. \& Gunlogson, C. (2009). An acoustic analysis of prosody in high-functioning autism. Applied Psycholinguistics, 30, 385-404.

Fay, W. \& Schuler, A. L. (1980).Emerginglanguage in autistic children. Baltimore: University Park Press.

Fosnot, S. \& Jun, S.-A. (1999). Prosodic characteristics in children with stuttering or autism during reading and imitation. Teoksessa Proceedings of the $14^{\text {th }}$ International Congress of Phonetic Sciences (ICPhS). Haettu 16.4.2019 osoitteesta https://www. internationalphoneticassociation.org/icphsproceedings/ICPhS1999/papers/p14_1925. pdf

Fine, J., Bartolucci, G., Ginsberg, G. \& Szatmari, P. (1991). The use of intonation to communicate in pervasive developmental disorders. Journal of Child Psychology and Psychiatry, 32, 771-782.

Ghaziuddin, M. \& Gerstein, L. (1996). Pedantic speaking style differentiates Asperger syndrome from high-functioning autism. Journal of Autism and Developmental Disorders, 26, 585-595.

Hakulinen, A. (1997). Vuorottelujäsennys. Teoksessa L. Tainio (toim.), Keskustelunanalyysin perusteet, (s. 32-55). Tampere: Vastapaino. 
Hirvonen, P. (1970). Finnish and English communicative intonation. Turku: Turun yliopisto.

Huhtamäki, M. (2015). En fråga om prosodi? Prosodiska drag hos fragor $i$ Helsingforssvenska samtal. Väitöskirja. Helsinki: Helsingin yliopisto.

Hutchby, I. \& Wooffitt, R. (2008). Conversation Analysis. [2. painos]. Cambridge: Polity Press.

Ihaksinen, K. (2019). Intonaation käyttö lievästi autististen varhaisnuorten spontaaneissa kuntoutuskeskusteluissa. Pro gradu -tutkielma, Helsinki: Helsingin yliopisto.

Iivonen, A. (1978). Is there interrogative intonation in Finnish? Teoksessa E. Gårding, G. Bruce \& R. Bannert (toim.), Nordic prosody. Papers from a symposium, (s. 43-53). Lund: Lund University.

Iivonen A. (1998). Intonation in Finnish. Teoksessa D. Hirst \& A. Di Cristo (toim.), Intonation systems: A survey of twenty languages, (s. 311-327). Cambridge: Cambridge University Press.

Iivonen, A. (2001). Intonation in Finnish questions. Teoksessa W. Van Dommelen \& T. Fretheim (toim.), Nordic prosody. Proceedings of the VIII ${ }^{\text {th }}$ conference, Trondheim 2000. Frankfurt am Main: Peter Lang.

Iivonen, A. (2006): Creaky Voice as a prosodic feature in Finnish. Teoksessa G. Bruce G. \& M. Horne (toim.), Nordic prosody. Proceedings of the IX conference, Lund 2004, (s. 137-146). Frankfurt am Main: Peter Lang.

Iivonen, A. (2009): Finnish sentence accent and intonation. Teoksessa V. de Silva \& R. Ullakonoja (toim.), Phonetics of Russian and Finnish. General description of phonetic systems. Experimental studies on spontaneous and readaloud speech, (s. 67-73). Frankfurt am Main: Peter Lang.

Iivonen, A. \& Aulanko, R. (toim.) (2001). Fonetiikan peruskäsitteitä. Helsinki: Helsingin yliopisto. Haettu 16.4.2019 osoitteesta http:// hdl.handle.net/10224/4622

Iivonen, A., Nevalainen, T., Aulanko, R. \& Kaskinen, H. (1987). Pubeen intonaatio. Helsinki: Gaudeamus.

Iso suomen kielioppi (ISK) (2004). A. Hakulinen, M. Vilkuna, R. Korhonen, V. Koivisto, T. R. Heinonen, \& I. Alho (toim.). Helsinki: SKS.
Kallioinen, V. (1968). Suomen kysymyslauseen intonaatiosta. Virittäjä, 72, 35-54.

Kremer-Sadlik, T. (2001). How children with autism and Asperger syndrome respond to questions: An ethnographic study. Väitöskirja. Los Angeles: University of California.

Kremer-Sadlik, T. (2004). How children with autism and Asperger syndrome respond to questions: a 'naturalistic' theory of mind task. Discourse Studies, 6, 185-205.

Lehtinen, M. (2006). Marqueurs du travail de formulation dans un corpus de français parlé. Teoksessa I. Taavitsainen, J. Härmä \& J. Korhonen J. (toim.), Dialogic language use / Dimensions du dialogisme / Dialogischer Sprachgebrauch. (s. 241-257). Helsinki: Société Néophilologique.

Lehtinen, M. (2010a). Observations on the prosodic characteristics of Finnish-speaking youngsters with Asperger Syndrome. Teoksessa A. Botinis (toim.), Proceedings of 'ExLing 2010 - ISCA Tutorial and Research Workshop on Experimental Linguistics,'Athens (Greece), August 24-26, 2010 (s. 93-96). Athens: ISCA / University of Athens.

Lehtinen, M. (2010b). The recategorisation of the rheme and the structure of the oral paragraph in French and in Finnish. Discours 7. Haettu 15.3.2020 osoitteesta http://discours.revues. org/8007

Lehtinen, M. (2012). "Aiheesta toiseen" Ymmärrysongelmatilanteita Asperger-nuorten kuntoutuskeskusteluissa. Teoksessa L. Leskelä \& C. Lindholm (toim.), Haavoittuva keskustelu. Keskustelunanalyyttisia tutkimuksia kielellisesti epäsymmetrisestä vuorovaikutuksesta (s. 235277). Helsinki: Kehitysvammaliitto.

McPartland, J. C. \& Klin, A. (2006). Asperger's syndrome. Adolescent Medicine Clinics, 17, 771-788.

Morel, M.-A. \& Danon-Boileau, L. (1998). Grammaire de l'intonation. L'Exemple du français oral. Paris / Gap: Ophrys.

Ogden, R. (2004). Non-modal voice quality and turn-taking in Finnish. Teoksessa E. Couper-Kuhlen \& C. E. Ford (toim.), Sound patterns in interaction, (s. 29-62). Amsterdam / Philadelphia: John Benjamins Publishing Company. 
Ogden, R. \& Routarinne, S. (2005). The communicative functions of final rises in Finnish intonation. Phonetica, 62, 160-175.

Olivati, A. G., Assumpção Jr, F. B. \& Nunes Misquiatti, A. R. (2017). Acoustic analysis of speech intonation pattern of individuals with Autism Spectrum Disorders. CoDAS, 2017/29(2). Haettu 16.4.2019 osoitteesta http://dx.doi.org/10.1590/2317$\underline{1782 / 20172016081}$

Ornitz, E. \& Ritvo, E. (1976). Medical assessment. Teoksessa E. Ritvo (toim.), Autism: Diagnosis, current research, and management, (s. 7-26). New York: Spectrum Publications.

Paul, R. (1987). Communication. Teoksessa D. Cohen \& A. Donnellan (toim.), Handbook of autism and pervasive developmental disorders, (s. 61-84). New York: Wiley.

Paul, R., Augustyn, A., Klin, A. \& Volkmar, F. R. (2005a). Perception and Production of Prosody by Speakers with Autism Spectrum Disorders. Journal of Autism and Developmental Disorders, 35, 205-220.

Paul, R., Shriberg, L., McSweeney, J., Cicchetti, D., Klin, A. \& Volkmar, F. R. (2005b). Brief report: relations between prosodic performance and communication and socialization ratings in high functioning speakers with autism spectrum disorders. Journal of Autism and Developmental Disorders, 35, 861-869.

Peppé, S., McCann, J., Gibbon, F., O’Hare, A., Rutherford, M. (2007). Receptive and Expressive Prosodic Ability in Children with High-Functioning Autism. Journal of Speech Language and Hearing Research, 50, 10151028.

Provonost, W., Wakstein, M. P. \& Wakstein, D. J. (1966). A longitudinal study of speech behavior and language comprehension in fourteen children diagnosed as atypical or autistic. Exceptional Children, 33, 19-26.

Routarinne, S. (2003). Tytöt ä̈nessä. Parenteesit ja nouseva sävelkulku kertojan vuorovaikutuskeinoina. Helsinki: SKS.

Rutter, M. \& Lockyer, L. (1967). A five to fifteen year follow-up study of infantile psychosis. I: Description of sample. British Journal of Psychiatry, 113, 1169-1182.
Ruusuvuori, J. (2016). Katse. Teoksessa M. Stevanovic \& C. Lindholm (toim.), Keskusteluanalyysi. Kuinka tutkia sosiaalista toimintaa ja vuorovaikutusta, (s. 47-62). Tampere: Vastapaino.

Sacks, H., Schegloff, E. \& Jefferson, G. (1974). A simplest systematics for the organization of turn-taking for conversation. Language, 50 , 696-735.

Seppänen, E.-L. (1997). Vuorovaikutus paperilla. Teoksessa L. Tainio (toim), Keskustelunanalyysin perusteet, (s. 18-31). Tampere: Vastapaino.

Shriberg, L., Rhea P., McSweeney, J., Klin, A., Cohen, D. \& Volkmar, F. R. (2001). Speech and prosody characteristics of adolescents and adults with high functioning autism and Asperger syndrome. Journal of Speech, Language and Hearing Research, 44, 1097-1115.

Simmons, J. \& Baltaxe, C. (1975). Language patterns in adolescent autistics. Journal of Autism and Childhood Schizophrenia, 5, 333351.

Solomon, O. (2001). Narrative Introduction Practices of Children with Autism and Asperger Syndrome. Väitöskirja. Los Angeles: University of California.

Solomon, O. (2004). Narrative introductions: Discourse competence of children with Autistic Spectrum Disorders. Discourse Studies, 6, 253276.

Stevanovic, M. (2016). Prosodia. Teoksessa M. Stevanovic \& C. Lindholm (toim.), Keskusteluanalyysi. Kuinka tutkia sosiaalista toimintaa ja vuorovaikutusta, (s. 100-121). Tampere: Vastapaino.

Szczepek Reed, B. (2009): Prosodic orientation: A practice for sequence organization in broadcast telephone openings. Journal of Pragmatics, 41, 1223-1247.

Tager-Flusberg, H. (1981). On the nature of linguistic functioning in early infantile autism. Journal of Autism and Developmental Disorders, $11,45-56$.

Tager-Flusberg, H. (2000). Understanding the language and communicative impairments in autism. Teoksessa L. M. Glidden (toim.), International Review of Research on Mental Retardation, Vol. 20, (s. 185-205). San Diego: Academic Press. 
Thomas, I. B. (1969). Perceived pitch of whispered vowels. The Journal of the Acoustical Society of America, 46(2B), 468-470.

Thorson, J. C., Usher, N., Patel, P. \& TagerFlusberg, H. (2016). Acoustic analysis of prosody in spontaneous productions of minimally verbal children and adolescents with autism. Teoksessa Proceedings of Speech Prosody 8, Boston, MA. Haettu 16.4.2019 osoitteesta http://www.bu.edu/bucld/files/2016/09/ BUCLD40 Thorson1.pdf

Van Bourgondien, M. \& Woods, A. (1992). Vocational possibilities for high functioning adults with autism. Teoksessa E. Schopler \& G. Mesibov (toim.), High functioning individuals with autism, (s. 227-242). New York: Plenum Press.

Wiklund, M. (2012). Gaze behavior of preadolescent children afflicted with Asperger Syndrome. Communication \& Medicine, 9, 173-186.

Wiklund, M. (2016). Interactional challenges in conversations with autistic preadolescents: The role of prosody and nonverbal communication in other-initiated repairs. Journal of Pragmatics, 94, 76-97.

Wiklund, M. \& Stevanovic, M. (2018). Ymmärrysongelmat ja vuorovaikutustaitojen opettaminen lievästi autististen varhaisnuorten kuntoutuskeskusteluissa. Psykologia, 53 (0506), 421-451.

Wiklund,M.\&Laakso,M.(2019).Ungrammatical utterances and disfluent speech as causes of comprehension problems in interactions of preadolescents with highly functioning autism. Clinical Linguistics \& Phonetics, 33, 654-676.

Wiklund, M. \& Vainio, M. (2019). Pitch-related features in the speech of Finnish- and Frenchspeaking boys with autism in data coming from group therapy sessions. Teoksessa J. Härmä, $\mathrm{H}$. E. H. Lenk, B. Sanromán Vilas \& E. SuomelaHärmä (toim.), Studies in Comparative Pragmatics (s. 45-63). Newcastle upon Tyne: Cambridge Scholars Publishing. 


\section{THE USE OF INTONATION IN QUESTIONS AND NARRATIVE TURNS IN THE SPONTANEOUS INTERACTION OF BOYS AFFLICTED WITH AUTISM SPECTRUM DISORDER}

Mari Wiklund, University of Helsinki, Department of Languages

Kia Ihaksinen, University of Helsinki, Department of Digital Humanities

Martti Vainio, University of Helsinki, Department of Digital Humanities

Autism spectrum disorder is a neurobiological developmental disorder, characterized e.g. by problems of social interaction, over-sensitivity to sensory stimuli as well as restricted interests (APA, 2013). People afflicted with autism spectrum disorder (ASD) often have deviant prosodic features in their speech. This article focuses on the utterance-final rising pitch and its use in questions and narrative turns in the spontaneous interaction of boys with ASD. The topic is important because even if autistic persons' prosodic features have already been studied rather extensively, spontaneous interaction, which allows observing the use of intonation by persons with ASD, has to date been studied very little.

The data originate from authentic group therapy sessions where 11-13-year-old boys afflicted with ASD talk with their therapists. Methods of phonetics and conversation analysis are used in the study.

The results of the study suggest that boys with ASD are able to use utterance-final rising pitch as an interactional resource as well as to produce and interpret correctly prosodic features that indicate finality in spontaneous interaction. They are also able to emphasize words with the help of prosodic features, call for other participants' reactions and indicate that they take other participants into account with the help of utterance-final pitch rises. Thus, boys with ASD seem to be able to use intonation as an interactional resource, even though reciprocal interaction is generally speaking difficult for people afflicted with autism (APA, 2013).

Keywords: autism, autism spectrum disorder, conversation analysis, interaction, intonation, prosody 